\title{
22- Yabancılar için Türkçe ders kitaplarındaki kültürel unsurların incelenmesi: Van Yüzüncü Yıl Üniversitesi yabancılar için Türkçe öğretim seti örneği ${ }^{123}$
}

Hilal YAZICI4

\section{Gökçen GÖÇEN5}

APA: Yazıcı, H.; Göçen, G. (2021). Yabancılar için Türkçe ders kitaplarındaki kültürel unsurların incelenmesi: Van Yüzüncü Yıl Üniversitesi yabancılar için Türkçe öğretim seti örneği. RumeliDE Dil ve Edebiyat Araşttrmaları Dergisi, (Ö10), 365-395. DOI: 10.2900o/rumelide.1011959.

$\ddot{O} \mathbf{z}$

Yabancı dil öğretimi sürecinde dilin kullanım boyutunu oluşturan kültürel unsurların büyük bir önemi vardır. Türkçenin yabancı dil olarak öğretiminde kültürel unsurların incelenmesine yönelik gerçekleştirilen çalışmalara bakıldı̆̆ında araştırmaların genellikle ders kitapları üzerine yapıldığı görülmektedir. Ders kitapları, ilk başvurulan ve en kolay ulaşılabilen kaynaklar olması bakımından hedef dil ve kültür öğretiminde önemli bir yere sahiptir. Bu sebeplerden ders kitaplarının kültürel açıdan incelenmesi bir ihtiyaç olarak görülmektedir. Bu çalışmada da inceleme alanı olarak ders kitaplarının seçilmesinde öğrenicilerin dil öğrenme sürecinde öncelikle ve genellikle ders kitaplarını kullanması etkili olmuştur. İlgili alanda yapılan çalışmalar araştırıldığında ilk basımları 2018-2020 yılları arasında yayımlanan Van Yüzüncü Yıl Üniversitesi Yabancılar için Türkçe ders kitaplarının kültürel unsurlar açısından incelenmediği fark edilmiştir. Türkçenin yabancı dil olarak öğretiminde ders kitapları aracılığıyla aktarılan kültürel unsurların belirlenmesinin ve bu yolla ders kitaplarının kültürel unsurlar açısından karşılaştırılmasının bir gereklilik olduğu düşünülmüştür. Buradan yola çıkarak çalışmada "Yabancılar için Türkçe ders kitaplarında yer alan kültürel unsurlar nelerdir?” araştırma sorusundan hareketle Van Yüzüncü Yıl Üniversitesi Yabancılar için Türkçe ders kitaplarında yer alan okuma metinlerindeki kültürel unsurların incelenmesi amaçlanmıştır. Nitel araştırma desenlerinden durum çalışmasına uygun olarak gerçekleştirilen çalışmada, kültürel unsurlara ait veriler doküman analiziyle toplanmıştır. Araştırma kapsamında incelenen kitaplarda kültürel unsurların en çok yiyecek, değerler, Türk edebiyatı, meslekler, turistik ve tarihî yerler boyutlarında kullanıldığı tespit edilmiştir.

Anahtar kelimeler: Yabancı dil öğretimi, Türkçenin yabancı dil olarak öğretimi, kültürel unsurlar, ders kitapları, hedef kültür aktarımı

\section{Examination of cultural elements in Turkish textbooks for foreigners: Van Yüzüncü Yıl University sample of Turkish teaching set for foreigners}

\author{
Abstract \\ Fatih Sultan Mehmet Vakıf Üniversitesi, Bilimsel Araştırma ve Yayın Etiği Kurulunun 2021-05/07 sayılı yazısı ile \\ araştırma için gerekli olan etik kurul izni alınmıştır. \\ Bu çalışma Gökçen GÖÇEN ÖZDEMİREL danışmanlığında Hilal YAZICI'nın aynı başlıkla 2021 yılında hazırladığı yüksek \\ lisans tezinden üretilmiștir. \\ Bu çalışma 10-11 Eylül 2021 tarihlerinde düzenlenen "7. Uluslararası Yabancı Dil Olarak Türkçe Öğretimi Kongresi"nde \\ sözlü bildiri olarak sunulmuştur. \\ YL Öğrencisi, Fatih Sultan Mehmet Vakıf Üniversitesi, Lisansüstü Eğitim Enstitüsü, Türkçe Öğretimi Programı (İstanbul, \\ Türkiye), hilal_yzc@hotmail.com, ORCID ID: oooo-0003-1643-4623 [Araştırma makalesi, Makale kayıt tarihi: \\ 24.09.2021-kabul tarihi: 20.10.2021; DOI: 10.29000/rumelide.1011959] \\ Doç. Dr., Fatih Sultan Mehmet Vakıf Üniversitesi, Türkçe Eğitimi ABD (İstanbul, Türkiye). ggocen@fsm.edu.tr, ORCID \\ ID: 0000000175528406 \\ RumeliDE Dil ve Edebiyat Araştırmaları Dergisi \\ Osmanağa Mahallesi, Mürver Çiçeği Sokak, No:14/8 \\ Kadıköy - ISTANBUL / TÜRKIYE 34714 \\ e-posta: editor@rumelide.com \\ tel: $+905057958124,+902167730616$ \\ Address \\ RumeliDE Journal of Language and Literature Studies \\ Osmanağa Mahallesi, Mürver Çiçeği Sokak, No:14/8 \\ Kadıköy - ISTANBUL / TURKEY 34714 \\ e-mail: editor@rumelide.com, \\ phone: +90 505 7958124, +90 2167730616
}




\begin{abstract}
Cultural elements that make up the dimension of language use have a great importance in the foreign language teaching process. When we look at the studies on the examination of cultural elements in the teaching of Turkish as a foreign language, it is seen that the researches are generally made on textbooks. Textbooks have an important position in target language and culture teaching as they are the first reference and the most easily accessible source. For these reasons, it was seen as a need to examine the textbooks from a cultural perspective. In this study, the choice of textbooks as a field of study was influenced by the fact that learners primarily and generally use textbooks in the language learning process. When the studies in the related field were investigated, it was noticed that the first editions of Van Yüzüncü Yıl University Turkish for Foreigners textbooks were not examined in terms of cultural elements. In teaching Turkish as a foreign language, it is thought that it is a necessity to determine the cultural elements transferred through the textbooks and to compare the textbooks in terms of cultural elements in this way. Based on the research question: "What are the cultural elements in Turkish textbooks for foreigners?” it was aimed to examine the cultural elements in the reading texts in Van Yüzüncü Yll University Turkish for Foreigners textbooks. In the study, which was carried out in accordance with the case study, one of the qualitative research designs, the data on cultural elements were collected by document analysis. In the books examined within the scope of the research, it has been determined that the cultural elements are mostly used in the dimensions of food, values, Turkish literature, professions, touristic and historical places.
\end{abstract}

Keywords: Foreign language teaching, teaching Turkish as a foreign language, cultural elements, textbooks, target culture transfer

\title{
1. Giriș
}

Dil ve kültür öğretimi birbirini desteklemektedir. Kültürden yoksun öğretilen bir dil, kurallardan ve sözcüklerden ibaret kalmaktadır. Kaplan’ın (2010, s. 151) belirttiği gibi dil, kültürün temeli olduğuna göre bir ulusun dil ile ifade ettiği sözlü, yazılı her şey kültür kavramına girmektedir. Bu bakımdan kültürün kapsamı oldukça geniştir. Dil, kültürün aynası olduğundan dil ile kültür birbirinden bağımsız düşünülememektedir (Abacığlu, 2002, s. 5). Ertuğrul'a (2015, s. 1) göre hedef dili doğru ve yerinde kullanabilmek için hedef kültürün de öğretimi gerekmektedir.

Türk gelenekleri, alışkanlıkları, yaşantı biçimi, değer yargıları, sosyal hayatı ve inançları gibi kültürel unsurların ders kitapları içindeki metinlerle sezdirilerek verilmesi, Türkçeyi hedef dil olarak öğrenen öğrenicilerin iletişimsel becerilerini arttırmaya ve doğru, kalıcı, zemini olan öğrenmelerin gerçekleşmesine yardımcı olmaktadır. Ders kitaplarında bulunan kültürel unsurların düzeylere göre hangi metinlerle, alıştırmalarla aktarılacağı bilindiğinde öğrenicilerin öğrenmeleri de daha doğru ve hatasız gerçekleşecektir. Karakoç Öztürk'e (2020, s. 291) göre ders kitaplarında kültürel unsurları verirken kullanılan bakış açısı, öğrenicinin hedef dili ve ona ait kültürün özünü öğrenmesini olumlu yahut olumsuz etkileyebilmektedir. Öğrenicilerin Türk kültürünü daha iyi, doğru, güncel ve ön yargısız bir şekilde öğrenebilmelerinde ders kitapları ihtiyaç duyulan bir misyonu üstlenmiş bulunmaktadır.

Türkçenin yabancı dil olarak öğretiminde ders kitapları birçok açıdan mihenk taşı görevindedir. Ders kitapları öğretim sürecinde en çok kullanılan araçlardır (Erdal, Dağdeviren, Gökhan, Şen ve Şenay, 2018, s. 22). Ders kitaplarındaki kültürel unsurlar Türkçenin doğru ve tam öğretilmesine, Türkiye'nin tanıtımına katkı sağlanmasına ve dolaylı da olsa Türkiye'nin turizm elçiliği görevini üstlenmesine yardımcı olmaktadır. Ayrıca ders kitaplarında yer alan kültürel unsurlar öğrenicilerin deyim, atasözü, özlü sözler, yan ve mecaz anlam gibi yoğun ifadeleri iyi anlayıp doğru söyleyebilmelerine katkıda

\footnotetext{
Adres | Address

RumeliDE Dil ve Edebiyat Araştırmaları Dergisi $\quad$ RumeliDE Journal of Language and Literature Studies Osmanağa Mahallesi, Mürver Çiçeği Sokak, No:14/8 Osmanağa Mahallesi, Mürver Çiçeği Sokak, No:14/8 Kadıköy - ÍSTANBUL / TÜRKIYE 34714 Kadıköy - ISTANBUL / TURKEY 34714 e-posta: editor@rumelide.com e-mail: editor@rumelide.com, tel: +90 505 7958124, +90 2167730616 phone: +90 505 7958124, +90 2167730616
} 
bulunmaktadır. Bu nedenle Türkçenin yabancı dil olarak öğretiminde ilk kaynak olarak görülen ders kitaplarında bulunan kültürel unsurların derinlemesine incelenip varsa eksiklerinin giderilerek yapılan çalışmalara katkı sağlanması gerekmektedir.

Türkçenin yabancı dil olarak öğretiminde ders kitaplarını kültürel yönden incelemenin alana sağlayacağı en önemli katkılarından biri de kültür aktarımı konusunda ölçüt geliştirilmesine yardımcı olmasıdır. Türkçenin yabancı dil olarak öğretimi üzerine yazılmış ders kitaplarında kültürel unsurlara yönelik ortak bir ölçütün geliştirilmesi ve kullanılması dil öğretimine ve kültür aktarımına destek olacaktır. Mutlu ve Set'e (2020, s. 94) göre ders kitaplarındaki kültürel unsurlar belirli kıstaslara göre öğrenicilere iletilmelidir. Bu kıstasları ortaya koymak, ders kitaplarındaki kültürel unsurların aktarımında ortak bir ölçüt kullanmak, ders kitaplarında verilen kültürel unsurlar arasındaki farklılı̆̆ ortadan kaldırmak, güncel kültürel unsurlara öncelik vermek ve hangi unsurdan hangi düzeyde ne kadar yararlanılması gerektiğini belirleyebilmek adına Türkçenin yabancı dil olarak öğretiminde ders kitaplarının kültürel unsurlar açısından incelenmesi önemlidir.

Okur ve Keskin'e (2013, s. 1638) göre kültürel unsurların bir öğretim setinde yer alan ders kitaplarına eşit dağılması da Türkçenin yabancı dil olarak öğretiminde kültür aktarımı konusunda dikkat edilmesi gerekenler arasındadır. Ders kitaplarındaki kültürel unsurların farklı dil seviyelerinde farklı yoğunluklarda verilmesi ya da bulundukları dil seviyesine uygun olmaması öğrenicilerin dili anlamlandırarak ilerlemesine ve sıralı olarak konuları birbiriyle ilişkili bir şekilde öğrenmesine engel teşkil edebilir. Bunlarla birlikte Bayraktar’n (2015, s. 8) belirttiği gibi farklı ders kitapları aracılığıyla öğrenicilere aktarılan farklı kültürel unsurlar güncelliğini korumalıdır.

Bu bağlamda ders kitaplarındaki kültürel unsurların incelenmesine kültür aktarımına yönelik bir ölçüt oluşturulması, düzeyler arası kültürel unsurların doğru dağılımının belirlenmesi, araştırmacılara ve eğitimcilere materyal geliştirme anlamında fikir verilmesi, farklı ders kitaplarından eğitim alan öğrenicilerin birbirinden bağımsız öğrenmelerinin önüne geçilmesi, güncel kültüre öncelik verilmesi gibi konular açısından ihtiyaç duyulmaktadır. Türkçenin yabancı dil olarak öğretiminde de ders kitaplarında kullanılan kültürel unsurların belirlenmesi farklı çalışmalarda hangi kültürel unsurların ne kadar kullanıldığının karşılaştırılması, elde edilen verilerin araştırmacılar tarafından değerlendirilmesi, ulaşılan sonuçlardan hareketle araştırmacıların gerekli çalışmaları gerçekleştirmesi ve geliştirmesi bakımından önemlidir.

"Türkçenin yabancı dil olarak öğretimi ve kültür" ile ilgili çalışmalara bakıldığında da çalışmalarda daha çok ders kitaplarının kültürel açıdan incelendiği görülmektedir (Akkoyunlu, 2019; Bayraktar, 2015; Çetinkaya, 2018; Ertuğrul, 2015; İşci 2012; Keskin, 2010; Kılıç, 2019; Koparan, 2019; Özgat Tatan, 2018; Sayid Açıkgöz, 2018; Sever, 2019; Tosun, 2016; Ummak, 2018; Ülker, 2007; Vargelen, 2013). İnceleme alanı olarak ders kitaplarının seçilmesinde, öğrenicilerin dil öğrenme sürecinde ilk olarak ders kitaplarıyla karşılaşmalarının etkisi büyüktür.

Yapılan çalışmalarda "Yeni Hitit”, "Gazi Yabancllar İçin Türkçe”, "Yedi İklim”, "Kolay Gelsin", "İstanbul", "Türkçeye Yolculuk", "Altay Türkçe Öğreniyorum” gibi Türkçeyi yabancı dil olarak öğrenenler için hazırlanan ders kitaplarındaki Türk kültürüne ait unsurların incelendiği görülmüştür. Araştırmalarda incelenen ders kitapları arasında Van Yüzüncü Yıl Üniversitesi Yabancılar için Türkçe öğretim setindeki ders kitaplarına rastlanmamıştır. Bu nedenle bu çalışmada "Yabancılar için Türkçe ders kitaplarında yer alan kültürel unsurlar nelerdir?” araştırma sorusundan hareketle Van Yüzüncü Yll Üniversitesi Yabancllar için Türkçe öğretim setinde yer alan temel (A1-A2), orta (B1-B2) ve ileri (C1-

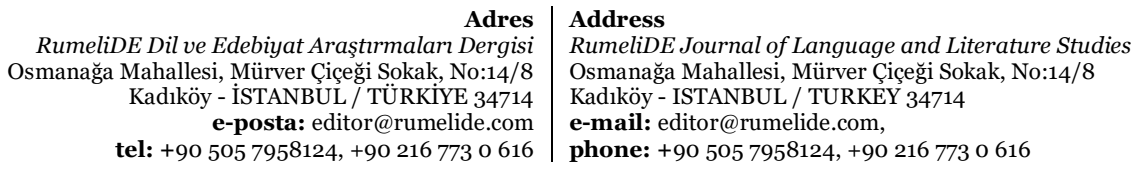


C2) düzey ders kitaplarında bulunan Türk kültürüne ait unsurların incelenmesi amaçlanmıştır. Bu amaçla yapılan çalışmanın alt amaçları ise şunlardır:

1. İncelenen ders kitaplarındaki kişilerarası iletişim unsurları nelerdir?

2. İncelenen ders kitaplarındaki ekonomik hayat unsurları nelerdir?

3. İncelenen ders kitaplarındaki milli spor unsurları nelerdir?

4. İncelenen ders kitaplarındaki yiyecek kültürü unsurları nelerdir?

5. İncelenen ders kitaplarındaki içecek kültürü unsurları nelerdir?

6. İncelenen ders kitaplarındaki müzik, müzik aletleri ve halk oyunları unsurları nelerdir?

7. İncelenen ders kitaplarındaki önemli şahsiyetler kimlerdir?

8. İncelenen ders kitaplarındaki atasözleri nelerdir?

9. İncelenen ders kitaplarındaki dini unsurlar nelerdir?

10. İncelenen ders kitaplarındaki kutlama ve festivallere yönelik unsurlar nelerdir?

11. İncelenen ders kitaplarındaki Türk adetleri nelerdir?

12. İncelenen ders kitaplarındaki değerler nelerdir?

13. İncelenen ders kitaplarındaki Türk edebiyatına ilişkin unsurlar nelerdir?

14. İncelenen ders kitaplarındaki görsel sanatlar nelerdir?

15. İncelenen ders kitaplarındaki meslekler nelerdir?

16. İncelenen ders kitaplarındaki turistlik ve tarihi yerler nereleridir?

Yapılan çalışmanın Türkçenin yabancı dil olarak öğretiminde kültür aktarımıyla ilgili alanda yapılan diğer çalışmalar için veri oluşturmaya ve yabancılar için Türkçe ders kitaplarıyla hangi kültürel unsurların aktarılması gerektiği konusuna ilişkin ortak bir ölçüt geliştirmeye katkı sağlayacağı düşünülmektedir.

\section{Yöntem}

Bu bölümde araştırmanın modeli, incelenen dokümanlar, verilerin toplanması ve analizi, araştırmanın güvenirliğine dair açıklamalarda bulunulmuştur.

\subsection{Araştırmanın modeli}

Van Yüzüncü Yıl Üniversitesi Yabancılar için Türkçe temel (A1, A2), orta (B1, B2) ve ileri (C1-C2) düzey ders kitaplarında bulunan okuma metinlerindeki kültürel unsurların araştıııldığı bu çalışma, nitel durum çalışması şeklinde desenlenmiştir. İncelenen ders kitaplarındaki bilgilerin düzenli, sistematik bir şekilde toplanması ve kültürel unsurların varlığının tespit edilebilmesi için durum çalışması seçilmiştir. Durum çalışması bir olayın ya da durumun ayrıntıya inerek boylamsal olarak incelendiği, düzenli biçimde verilerin toplandığı ve toplanan bu verilere ortamın gerçekliğinde bakıldı̆̆ bir yöntemdir (Subaşı ve Okumuş, 2017, s. 420). Bu yöntemin en temel özelliği incelenen durumun derinlemesine araştırılmasıdır (Yıldırım ve Şimşek, 2016, s. 77). Bütünlük gerektiren yoğun incelemelerde, durum çalışmasının güçlü bir rehber olabileceği, karmaşıklıkların anlaşılmasına ve keşfedilmesine yardımcı olabileceği söylenebilir (Ozan Leymun, Odabaşı ve Kabakçı Yurdakul, 2017, s. 371).

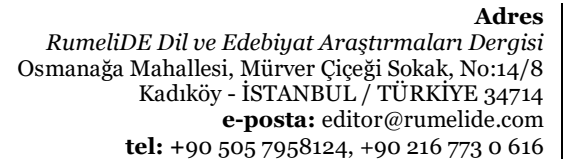

RumeliDE Dil ve Edebiyat Araştırmaları Dergisi Kadıköy - İSTA tel: +90 505 7958124, +902167730616
Address

RumeliDE Journal of Language and Literature Studies

Osmanağa Mahallesi, Mürver Çiçeği Sokak, No:14/8

Kadıköy - ISTANBUL / TURKEY 34714

e-mail: editor@rumelide.com,

phone: +90 505 7958124, +90 2167730616 


\section{2. İncelenen dokümanlar}

Çalışmada, Van Yüzüncü Yıl Üniversitesi Yabancılar için Türkçe temel (A1, A2), orta (B1, B2), ileri (C1C2) düzey ders kitapları incelenmiştir. Çalışma kapsamında incelenen ders kitaplarına dair bilgiler aşağıdaki şekildedir:

Tablo 1. Çalışma kapsamında incelenen dokümanlar

\begin{tabular}{llll}
\hline Dil Düzeyi & Yayınevi & Basım Yılı & $f$ \\
\hline Temel Düzey A1 & Hiperyayın & 1. Baskı, 2018 & 1 \\
Temel Düzey A2 & Hiperyayın & 1. Baskı, 2019 & 1 \\
Orta Düzey B1 & Hiperyayın & 1. Baskı, 2019 & 1 \\
Orta Düzey B2 & Hiperyayın & 1. Baskı, 2019 & 1 \\
İleri Düzey (C1-C2) & Hiperyayın & 1. Baskı, 2020 & 1 \\
Toplam & & & 5 \\
\hline
\end{tabular}

Çalışma kapsamında Van Yüzüncü Yıl Üniversitesi Yabancılar için Türkçe öğretim setinde yer alan toplam 5 ders kitabı doküman olarak incelenmiştir.

\subsection{Verilerin toplanması}

Yapılan araştırmada ders kitaplarındaki kültürel unsurlara yönelik veriler, ders kitaplarında yer alan okuma metinlerinden elde edilmiştir. Seçilen ders kitaplarında yer alan ve araştırma kapsamında incelenen okuma metinlerinin sayısı şu şekildedir: A1 ders kitabında 19; A2 ders kitabında 20; B1 ders kitabında 22; B2 ders kitabında 32; C1-C2 ders kitabında ise 46.

Yapılan çalışma kapsamında seçilen ders kitaplarındaki kültürel unsurlara yönelik veriler doküman analiziyle toplanmıştır. Araştırma konusuyla ilgili yazılı materyallerin analizini kapsayan doküman analizi (Yıldırım ve Şimşek, 2016, s. 187), basılı ve elektronik olması şartıyla bütün belgeleri tetkik etmek ve değerlendirmek amacıyla kullanılan sistemli bir yöntemdir (Kıral, 2020, s. 173).

\subsection{Verilerin analizi}

Van Yüzüncü Yıl Üniversitesi Yabancılar için Türkçe öğretim setinde yer alan ders kitaplarındaki kültürel unsurlara ilişkin verilerin analizinde içerik analizinden yararlanılmıştır. İçerik analizi kapsamında öncelikle kültürel unsurların hangi boyutlarda tespit edileceği araştırılmıştır. Alanyazın taraması sonucundan hareketle seçilen kültürel boyutlara göre ders kitaplarındaki kültürel unsurlar incelenmiştir. Ders kitaplarında bulunan kültürel unsurlar tespit edilmiş ve unsurlar ilgili kültürel boyutlara ilişkin tablolara yerleştirilmiştir.

Kültürel boyutların seçilmesi amacıyla yapılan alanyazın taramasında konuyla ilgili farklı çalışmaların yapıldığı ve çalışmalarda farklı kültürel boyutların temel alındığı görülmüş̧ür. Ders kitaplarındaki kültürel unsurları inceleyen çalışmalar şu şekilde özetlenebilir: Okur ve Keskin'in (2013) yabancılar için Türkçe ders kitaplarındaki kültürel unsurların incelenmesine yönelik yaptıkları çalışmada kullandıkları boyutlar; günlük yaşam, kişiler arası ilişkiler, değerler ve eğitim, edebiyat-sanat ve müzik, gelenekler ve folklor, sosyal yaşam, coğrafya ile mekân şeklindedir. Ertuğrul'un (2015) yüksek lisans tezinde Türkçenin yabancı dil olarak öğretimi alanında kullanılan kitaplardaki kültürel unsurları incelemek için seçtiği boyutlar ise şunlardır: Kişiler arası iletişim; ekonomik hayat; millî spor; yiyecek kültürü; içecek 
kültürü; müzik, müzik aletleri ve halk oyunları; önemli şahsiyetler; atasözleri; dinî unsurlar; kutlama ve festivaller; Türk âdetleri; değerler; Türk edebiyatı; görsel sanatlar; meslekler; turistik ve tarihî yerler. Tosun'un (2016) yabancılar için Türkçe ders kitaplarındaki kültürel unsurları incelediği yüksek lisans tezinde kullandığı boyutlar; dil, sinema, edebiyat, tarih, değerler, müzik, plastik sanatlar, el sanatları ve mimaridir. Sever’in (2019) yüksek lisans tezinde yabancılar için Türkçe ders kitaplarını kültür aktarımı bakımından incelemek için seçtiği boyutlar ise günlük yaşam, yaşam koşulları, kişiler arası ilişkiler, değerler, inançlar ve davranışlar, beden dili, sosyal gelenekler, âdet olmuş davranışlardır.

Yabancılar için Türkçe ders kitaplarındaki kültürel unsurların incelenmesine yönelik yapılan farklı çalışmalarda kullanılan kültürel boyutlara bakıldığında kişiler arası iletişim, değerler, edebiyat gibi ortak ya da coğrafya ile mekân, turistik ve tarihî yerler, mimari gibi birbirine yakın olan boyutlara rastlanmaktadır. Birçok çalışmada ifade edilen boyutlar, Okur ve Keskin’in (2013) kullandığı boyutlarla benzerlik göstermektedir ancak Ertuğrul'un (2015) çalışmasındaki boyutlar dil seviyeleriyle de ilişkilendirilerek daha fazla alt boyuta ayrılmıştır. Yapılan bu çalışmada inceleme kolaylığı sağlaması açısından ve birçok çalışmadan (Brooks, 1986; Bölükbaş ve Keskin, 2010; Kara, 2011; Kolaç, 2009; Okur ve Keskin, 2013; Ökten ve Kavanoz, 2014; Özdemir, 2013; Pehlivan, 2007; Tüm ve Sarkmaz, 2012; Ülker, 2007'den aktaran Ertuğrul, 2015) yararlanılarak seçilmiş olan Ertuğrul'un (2015) çalışmasındaki kültürel boyutlar kullanılmıştır.

\subsection{Araştırmanın güvenirliği}

Çalışma kapsamında öncelikle Van Yüzüncü Yıl Üniversitesi Yabancılar için Türkçe öğretim setindeki ders kitaplarında yer alan okuma metinlerindeki kültürel unsurlar tespit edilmiş ve unsurlar ilgili kültürel boyutlara yerleştirilmiştir.

Çalışma kapsamında benzer bir işlem Türkçe eğitimi alan uzmanı tarafından da gerçekleştirilmiştir. Tespit edilen kültürel unsurlar, alan uzmanı tarafından da ilgili kültürel boyutlara yerleştirilmiştir. Kültürel unsurların ilgili kültürel boyutlara dağılımının sağlanmasının ardından araştırmacı ve alan uzmanı arasındaki uyum incelenmiş̧tir. Bu süreçte Miles ve Huberman'ın (1994, s. 64) ortaya koyduğu "Güvenirlik = görüsş birliği / görüş birliği + görüş ayrılığı" formülünden faydalanılmıştır. Çalışmanın güvenirliği bütün kültürel unsurlar için genel olarak ve temel, orta, ileri olmak üzere dil düzeylerine göre hesaplanmıştır.

Bu bağlamda yapılan çalışmanın genel olarak güvenirliği incelendiğinde ders kitaplarında toplam 1083 kültürel unsurun tespit edildiği ve görüş ayrılı̆̆ına dair unsur sayısının ise 30 olduğu görülmüştür. Bu veriler formülle (Miles ve Huberman, 1994) ifade edildiğinde sonuç şu şekilde çıkmaktadır: $1053 / 1053+30=0,97$.

Çalışmanın güvenirliği dil düzeylerine göre değerlendirildiğinde ise şu verilerle karşılaşılmıştır: Temel düzey (A1-A2) ders kitaplarındaki kültürel unsurların güvenirliği incelendiğinde ders kitaplarında 219 kültürel unsur tespit edilmiştir. Görüş ayrılığına dair unsur sayısı ise 6'dır. Veriler formüle (Miles ve Huberman, 1994) yerleştirildiğinde sonuç şu olmaktadır: 213/213+6=0,97. Orta düzey (B1-B2) ders kitaplarındaki kültürel unsurların güvenirliği incelendiğinde ders kitaplarında 414 kültürel unsur tespit edilmiştir. Görüş ayrılığına dair unsur sayısı ise 4'tür. Veriler formüle (Miles ve Huberman, 1994) yazıldığında sonuç şu şekildedir: 410/410+4=0,99. İleri düzey $(\mathrm{C} 1-\mathrm{C} 2)$ ders kitabındaki kültürel unsurların güvenirliği incelendiğinde ise ders kitaplarında 450 kültürel unsur tespit edilmiştir. Görüş

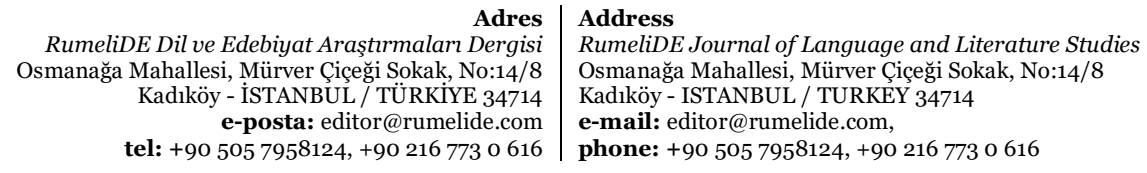


ayrılığına dair unsur sayısı ise 22'dir. Veriler bir formülle (Miles ve Huberman, 1994) şu şekilde ifade edilebilir: $428 / 248+22=0,95$.

Nitel araştırmalarda çalışmanın güvenirliğini sağlayabilmek için araştırmacı ve uzman arasındaki uyumun \%90 ve üzeri olması gerekmektedir (Saban, 2008, s. 467). Bu bağlamda yabancılar için Türkçe ders kitaplarında var olan kültürel unsurların tespitine yönelik yapılan bu çalışmadan elde edilen verilerin güvenirliği sağladığı görülmektedir.

\section{Bulgular ve yorum}

Yapılan çalışma kapsamında Van Yüzüncü Yıl Üniversitesi Yabancılar için Türkçe öğretim setinde yer alan kitaplarda kişiler arası iletişim, ekonomik hayat, millî spor, yiyecek kültürü, içecek kültürü, müzik, müzik aletleri ve halk oyunları, önemli şahsiyetler, atasözleri, dinî unsurlar, kutlama ve festivaller, Türk âdetleri, değerler, Türk edebiyatı, görsel sanatlar, meslekler, turistik ve tarihî yerlere ilişkin unsurlar kültürel boyutlarına göre incelenmiş ve elde edilen veriler bu bölümde sunulmuştur.

\subsection{Ders kitaplarındaki kişiler arası iletişim unsurlarına yönelik bulgular ve yorum}

Bu bölümde araştırma kapsamında incelenen ders kitaplarında yer alan iletişim boyutuna yönelik kültürel unsurlar ve bu unsurların sıklıkları tablo şeklinde sunulmaktadır.

İncelenen ders kitaplarında iletişim boyutunda yer alan kültürel unsurlar şunlardır:

Tablo 2. Kişiler arası iletişim boyutuna göre ders kitaplarında yer alan kültürel unsurlar

\begin{tabular}{l|l|l}
\hline Dil Düzeyi & Kültürel Unsurlar & $f$ \\
\hline $\begin{array}{l}\text { Temel Düzey (A1- } \\
\text { A2) }\end{array}$ & $\begin{array}{l}\text { Merhaba, memnun oldum, teşekkür ederim, günaydın, iyi akşamlar, iyi } \\
\text { geceler, görüşürü, hoşça kal, hoş geldiniz, hoş bulduk, lütfen, afiyet } \\
\text { olsun, ellerine sağlık, buyurun, iyi günler, iyi uçuşlar, tamam, rica } \\
\text { ederim, kendinize iyi bakı, görüşmek üzere, affedersiniz, tabi, elbette }\end{array}$ & 23 \\
\hline $\begin{array}{l}\text { Orta Düzey (B1- } \\
\text { B2) }\end{array}$ & & 0 \\
\hline $\begin{array}{l}\text { Ileri Düzey (C1- } \\
\text { C2) }\end{array}$ & $\begin{array}{l}\text { Teşekkür etmek, hoş geldin, selamünaleyküm, aleykümselam, } \\
\text { teşekkürler, selam }\end{array}$ & 6 \\
\hline Toplam & & 29 \\
\hline
\end{tabular}

Tablo 2'ye bakıldığında kişilerarası iletişime ilişkin temel düzey (A1-A2) ders kitaplarında 23; orta düzey (B1-B2) ders kitaplarında o; ileri düzey (C1-C2) ders kitabında 6 ve toplamda ise 29 unsura rastlanmaktadır. Kişiler arası iletişim boyutunda en fazla temel düzey (A1-A2) ders kitaplarında unsur bulunmaktadır. Orta düzey (B1-B2) ders kitaplarında kişiler arası iletişimle ilgili ifadeye rastlanmamaktadır.

Temel düzey (A1-A2) ders kitaplarında bulunan kişiler arası iletişim boyutunda günlük hayatta kişiler arası iletişimde kullanılan "merhaba, memnun oldum, teşekkür ederim, günaydın, iyi akşamlar, iyi geceler, görüşürüz, hoşça kal, hoş geldiniz, hoş bulduk, lütfen, afiyet olsun, ellerine sağlik, buyurun, iyi günler, iyi uçuşlar, tamam, rica ederim, kendinize iyi bakın, görüşmek üzere, affedersiniz, tabi, elbette" kelime ve kelime gruplarına rastlanmaktadır. İleri düzey (C1-C2) ders kitabında ise temel düzey (A1-A2) ders kitaplarında kullanılan "teşekkür etmek, hoş geldin" ifadeleri tekrar kullanılmıştır. İleri

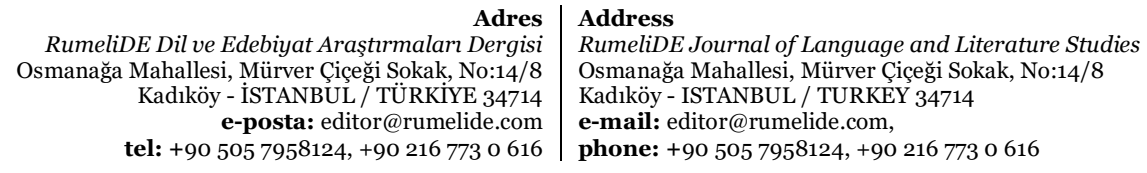


düzey (C1-C2) ders kitabında yeni olarak "selamünaleyküm, aleykümselam, selam” ifadeleri kullanılmıştır.

\subsection{Ders kitaplarındaki ekonomik hayat unsurlarına yönelik bulgular ve yorum}

Bu bölümde araştırma kapsamında incelenen ders kitaplarında yer alan ekonomik hayat boyutuna yönelik kültürel unsurlar ve bu unsurların sıklıkları tablo şeklinde sunulmaktadır.

İncelenen ders kitaplarında ekonomik hayat boyutunda yer alan kültürel unsurlar şunlardır:

Tablo 3. Ekonomik hayat boyutuna göre ders kitaplarında yer alan kültürel unsurlar

\begin{tabular}{l|l|l}
\hline Dil Düzeyi & Kültürel Unsurlar & $f$ \\
\hline $\begin{array}{l}\text { Temel Düzey (A1- } \\
\text { A2) }\end{array}$ & $\begin{array}{l}\text { Ne kadar, ücret, finans, ekonomi, ticari, tasarruf, pahalı, masraflı, işsizlik, sanal } \\
\text { para, bitcoin, yoksul, zengin }\end{array}$ & 13 \\
\hline $\begin{array}{l}\text { Orta Düzey (B1- } \\
\text { B2) }\end{array}$ & $\begin{array}{l}\text { Ticari maksat, ticari kazanç, para, alışveriş, müşteri, ekonomik sıkıntı, para } \\
\text { biriktirmek }\end{array}$ & 7 \\
\hline $\begin{array}{l}\text { İleri Düzey (C1- } \\
\text { C2) }\end{array}$ & $\begin{array}{l}\text { Maden yatakları, ticaret, verimli topraklar, parayı kullanan ilk medeniyet, tarım } \\
\text { ve hayvancılık, Kral Yolu, dokuma tezgâhı, ihtiyaç fazlasını satmak, geçimini } \\
\text { sağlamak, pazar, bakkal, dükkân, terazi, dirhem, ödünç para, borç, alacaklı, } \\
\text { kese, akçe, peşin para, fakir fukara, para kazanmak, açözlü, cimri, müşteri, } \\
\text { yoksul, maliyet kısmak, finansal kaynak, maliyet, okka, ekmek parası, ücretli, } \\
\text { hasılat, para ödemek, hesap kapatmak, para ihtiyacı, ödeme, pahalı, aylık }\end{array}$ & 39 \\
\hline Toplam & & 59 \\
\hline
\end{tabular}

Tablo 3 incelendiğinde ekonomik hayat unsurlarından temel düzey (A1-A2) ders kitaplarında 14; orta düzey (B1-B2) ders kitaplarında 7; ileri düzey (C1-C2) ders kitabında 39 ve toplamda 60 unsurla karşılaşılmaktadır. İleri düzey (C1-C2) ders kitabında kullanılan ifadelerin sayısı, temel düzey (A1-A2) ve orta düzey (B1-B2) ders kitaplarına göre artış göstermiştir.

Genel olarak ders kitaplarının her düzeyinde ekonomik hayatla ilgili farklı kavramlar kullanılmıştır. Orta düzey (B1-B2) ve ileri düzey (C1-C2) ders kitaplarında "müşteri”; temel düzey (A1-A2) ve ileri düzey (C1-C2) ders kitaplarında ise "yoksul, pahalı" kelimeleri ortak olarak kullanılmıştır.

\subsection{Ders kitaplarındaki millî spor unsurlarına yönelik bulgular ve yorum}

Bu bölümde araştırma kapsamında incelenen ders kitaplarında yer alan millî spor boyutuna yönelik kültürel unsurlar ve bu unsurların sıklıkları tablo şeklinde sunulmaktadır.

İncelenen ders kitaplarında millî spor boyutunda yer alan kültürel unsurlar şunlardır:

Tablo 4. Millî spor boyutuna göre ders kitaplarında yer alan kültürel unsurlar

\begin{tabular}{l|l|l}
\hline Dil Düzeyi & Kültürel Unsurlar & $f$ \\
\hline $\begin{array}{l}\text { Temel Düzey (A1- } \\
\text { A2) }\end{array}$ & Bisiklet sürmek, yürüyüş & 2 \\
\hline $\begin{array}{l}\text { Orta Düzey (B1- } \\
\text { B2) }\end{array}$ & $\begin{array}{l}\text { Boks, kick-boks, fitness, voleybol, basketbol, squash, masa tenisi, tenis, pilates, } \\
\text { yürüyüs, koşmak, bisiklet sürmek, futbol, yüzme, su sporu, sirtüstü yüzme, } \\
\text { kurbağalama yüzme, serbest yüzme, kelebek yüzme, karışlk yüzme, karate }\end{array}$ & 21 \\
\hline $\begin{array}{l}\text { İleri Düzey (C1- } \\
\text { C2) }\end{array}$ & Cirit oynamak, egzersiz yapmak, tırmanış & 3 \\
\hline
\end{tabular}

RumeliDE Dil ve Edebiyat Araştırmaları Dergisi Osmanağa Mahallesi, Mürver Çiçeği Sokak, No:14/8 Kadıköy - ÍSTANBUL / TÜRKIYE 34714 e-posta: editor@rumelide.com tel: +90 505 7958124, +90 2167730616
Address

RumeliDE Journal of Language and Literature Studies Osmanağa Mahallesi, Mürver Çiçeği Sokak, No:14/8

Kadıköy - ISTANBUL / TURKEY 34714

e-mail: editor@rumelide.com

phone: +90 505 7958124, +90 2167730616 


\begin{tabular}{l|l|l}
\hline Toplam & 26 \\
\hline
\end{tabular}

Tablo 4'e göre millî spor boyutunda temel düzey (A1-A2) ders kitaplarında 2; orta düzey (B1-B2) ders kitaplarında 21; ileri düzey (C1-C2) ders kitabında 3 ve toplamda 26 unsur kullanılmıştır. Ders kitaplarında en fazla unsurun orta düzey (B1-B2) ders kitaplarında kullanıldı̆̆ı görülmektedir.

Temel düzey (A1-A2) ders kitaplarında geçen "bisiklet sürmek ve yürüyüş” sporları orta düzey (B1-B2) ders kitaplarında da kullanılmıştır. Düzeyler arasında ortak kullanılan başka millî spor unsuruna rastlanmamaktadır.

\subsection{Ders kitaplarındaki yiyecek kültürü unsurlarına yönelik bulgular ve yorum}

Bu bölümde araştırma kapsamında incelenen ders kitaplarında yer alan yiyecek kültürü boyutuna yönelik kültürel unsurlar ve bu unsurların sıklıkları tablo şeklinde sunulmaktadır.

İncelenen ders kitaplarında yiyecek kültürü boyutunda yer alan kültürel unsurlar şunlardır:

Tablo 5. Yiyecek kültürü boyutuna göre ders kitaplarında yer alan kültürel unsurlar

\begin{tabular}{|c|c|c|}
\hline Dil Düzeyi & Kültürel Unsurlar & $f$ \\
\hline $\begin{array}{l}\text { Temel Düzey (A1- } \\
\text { A2) }\end{array}$ & $\begin{array}{l}\text { Kahvaltı, peynir, zeytin, reçel, yumurta, bal, kantin, akşam yemeği, piknik, } \\
\text { boyoz, fistık, inci kefali, Van'ın mutfă̆ı, öğlen yemeği, kebap, döner, iskender, } \\
\text { Türk yemekleri, çiğköfte, kızartma, konserve ürünler, paketlenmiş gıdalar, } \\
\text { yoğurt, enginar, kabak, brokoli, lahana, ıspanak, sebze, yeşil sebzeler, } \\
\text { beslenme, sağlıklı beslenme, abur cubur, obezite, dengesiz beslenme, } \\
\text { atıştırmalıklar }\end{array}$ & 36 \\
\hline $\begin{array}{l}\text { Orta Düzey (B1- } \\
\text { B2) }\end{array}$ & $\begin{array}{l}\text { Greyfurt, elma, karpuz, sarımsak, domates, beyaz lahana, turunçgil, Türk } \\
\text { mutfağı, armut, balık, tuz, market, beslenme alışkanlıkları, fast food, } \\
\text { restoran, iştah, firın, bitki, hamur, mısır, mantar, peynir, soğan, zeytin, biber, } \\
\text { dondurma, meyve, tereyağı, pirinç, yöresel lezzetler }\end{array}$ & 30 \\
\hline $\begin{array}{l}\text { İleri Düzey (C1- } \\
\text { C2) }\end{array}$ & $\begin{array}{l}\text { Beslenme alışkanlığı, damak zevki, tarımsal üretim, mutfak kültürü, tahıl, } \\
\text { sebze, zeytinyağlı, hamur işi, etle sulu olarak hazırlanan yemekler, pekmez, } \\
\text { yoğurt, bulgur, Türk mutfăı, Gaziantep mutfağı, kebap, et yemekleri, } \\
\text { yoğurtlu yemekler, zeytinyağlı yemekler, tatlı, pilav, sebze yemekleri, köfte, } \\
\text { börek, salata ve piyaz, dolma, Kanarya Kebap, Mevlana Kebap, Ali Nazik } \\
\text { Kebap, Kâğı̆ı Kebabı, Tandır Kebabı, Beyti, tahıl ve hamur/unla hazırlanan } \\
\text { çorbalar, kuru baklagillerle hazırlanan çorbalar, et ve sakatat çorbaları, tavuk } \\
\text { ve diğer kümes hayvanı etleriyle hazırlanan çorbalar, yoğurt ve sütle } \\
\text { hazırlanan çorbalar, sebze çorbaları, Lebeniye Çorbası, Soğan Çorbası, } \\
\text { Yalancı Paça Çorbası, Nohut Çorbası, Bıt Bıt Çorbası, Kırmızı Mercimek } \\
\text { Çorbası, Şehriye Çorbası, tutmaç Çorbası, Sebzeli Buğday Çorbası, Ezogelin } \\
\text { Çorbass, Sütlü Sebze Çorbası, Domates Çorbası, Tarhana Çorbası, Yayla } \\
\text { Çorbası, Aş Otu Çorbası, Hanım Ağa Çorbası, Çeşm-i Nigar Çorbası, Kavata } \\
\text { Çorbası, Süleymaniye Çorbası, Meyir Çorbası, Kuş Çorbası, damak tadı, } \\
\text { sağlıklı beslenme, dengeli beslenme, vejeteryan mutfağı, ikram etmek, aç } \\
\text { yatmak, karnını doyurmak, ekmek, şeker, susam, arpa, buğday, açlıktan } \\
\text { kıvranma, kabak, ceviz, çömlek, et, vitamin ve mineral bakımınnan zengin } \\
\text { yiyecekler, üzüm, fast food, rafineri gıdalar, katkı maddeli yiyecekler, unlu } \\
\text { gıdalar, tuz, katı yağlar, hormonlu gıdalar, bal, propolis, polen, arı sütü, sebze, } \\
\text { meyve, lokma, zahire, balık, restoran, yahni, fesleğen, zencefil, tarçın, badem, } \\
\text { ziyafet çekmek, bir deri bir kemik kalmak }\end{array}$ & 101 \\
\hline Toplam & & 167 \\
\hline
\end{tabular}

Tablo 5’te görüldüğü gibi yiyecek kültürü boyutunda temel düzey (A1-A2) ders kitaplarında 36; orta düzey (B1-B2) ders kitaplarında 30; ileri düzey (C1-C2) ders kitabında 101 ve toplamda 167 unsur

\footnotetext{
Adres | Address

RumeliDE Dil ve Edebiyat Araştırmaları Dergisi $\quad$ RumeliDE Journal of Language and Literature Studies Osmanağa Mahallesi, Mürver Çiçeği Sokak, No:14/8 $\quad$ Osmanağa Mahallesi, Mürver Çiçeği Sokak, No:14/8 Kadıköy - ÍSTANBUL / TÜRKIYE 34714 Kadıköy - ISTANBUL / TURKEY 34714 e-posta: editor@rumelide.com e-mail: editor@rumelide.com, tel: +90 505 7958124, +90 2167730616 phone: +90 505 7958124, +90 2167730616
} 
kullanılmıştır. İleri düzey (C1-C2) ders kitabında geçen yemek kültürüne ait unsurların sayısı temel düzey (A1-A2) ve orta düzey (B1-B2) ders kitaplarına göre artış göstermektedir.

Temel düzey (A1-A2) ders kitaplarında geçen "peynir, zeytin, lahana”, orta düzey (B1-B2) ders kitaplarında da geçmektedir. Temel düzey (A1-A2) ders kitaplarında kullanılan “kebap” ileri düzey (C1C2) ders kitabında da "Mevlana Kebap, Ali Nazik Kebap, Kâğıt Kebabı, Tandır Kebabı, Beyti" kebap çeşitleriyle beraber kullanılmıştır. Temel düzey (A1-A2) ders kitaplarında kullanılan "yoğurt, kabak" yiyecekleri ileri düzey (C1-C2) ders kitabında da kullanılmıştır. Orta düzey (B1-B2) ders kitaplarında kullanılan "bahk, tuz, soğan" besinleri ileri düzey (C1-C2) ders kitabında da geçerek tekrarlanmıştır. İleri düzey (C1-C2) ders kitabında çorba ve kebap çeşitlerine yer verilmiştir. İleri düzey (C1-C2) ders kitabında yemek çeşitleriyle beraber besin çeşitleri de sayıca artarak verilmiştir.

\subsection{Ders kitaplarındaki içecek kültürü unsurlarına yönelik bulgular ve yorum}

Bu bölümde araştırma kapsamında incelenen ders kitaplarında yer alan içecek kültürü boyutuna yönelik kültürel unsurlar ve bu unsurların sıklıkları tablo şeklinde sunulmaktadır.

İncelenen ders kitaplarında içecek kültürü boyutunda yer alan kültürel unsurlar şunlardır:

Tablo 6. İçecek Kültürü Boyutuna Göre Ders Kitaplarında Yer Alan Kültürel Unsurlar

\begin{tabular}{l|l|l}
\hline Dil Düzeyi & Kültürel Unsurlar & $f$ \\
\hline $\begin{array}{l}\text { Temel Düzey (A1- } \\
\text { A2) }\end{array}$ & Çay, kahve, ayran, su & 4 \\
\hline $\begin{array}{l}\text { Orta Düzey (B1- } \\
\text { B2) }\end{array}$ & Su & 1 \\
\hline $\begin{array}{l}\text { İleri Düzey (C1- } \\
\text { C2) }\end{array}$ & Su, alkol, salep, çay & 4 \\
\hline Toplam & & 9 \\
\hline
\end{tabular}

Tablo 6 incelediğinde içecek kültürü boyutunda temel düzey (A1-A2) ders kitaplarında 4; orta düzey (B1B2) ders kitaplarında 1; ileri düzey (C1-C2) ders kitabında 4 ve toplamda 9 unsur kullanıldığı görülmüştür. İçecek kültürüne ilişkin en fazla unsura ileri düzey (C1-C2) ders kitabında rastlanmaktadır.

İçecek kültürü boyutu incelendiğinde "su" her düzey ders kitabında kullanılmıştır. Temel düzey (A1-A2) ders kitaplarında "çay, kahve, ayran, su"; orta düzey (B1-B2) ders kitaplarında yalnızca "su”; ileri düzey (C1-C2) ders kitabında ise "su, alkol, salep, çay" içecek ifadeleri kullanılmıştır.

\subsection{Ders kitaplarındaki müzik, müzik aletleri ve halk oyunları unsurlarına yönelik bulgular ve yorum}

Bu bölümde araştırma kapsamında incelenen ders kitaplarında yer alan müzik, müzik aletleri ve halk oyunları boyutuna yönelik kültürel unsurlar ve bu unsurların sıklıkları tablo şeklinde sunulmaktadır.

İncelenen ders kitaplarında müzik, müzik aletleri ve halk oyunları boyutunda yer alan kültürel unsurlar şunlardır:

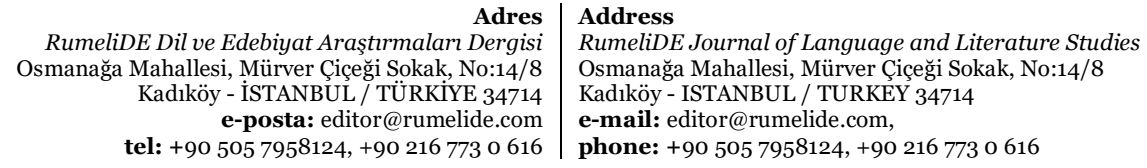


Tablo 7. Müzik, müzik aletleri ve halk oyunları boyutuna göre ders kitaplarında yer alan kültürel unsurlar

\begin{tabular}{l|l|l}
\hline Dil Düzeyi & Kültürel Unsurlar & $f$ \\
\hline $\begin{array}{l}\text { Temel Düzey (A1- } \\
\text { A2) }\end{array}$ & $\begin{array}{l}\text { Piyano, gitar, ney, şarkı söylemek, dans etmek, bale yapmak, saz heyeti, Türk } \\
\text { Sanat Müziği, Türk Halk Müziği, türkü }\end{array}$ & 10 \\
\hline $\begin{array}{l}\text { Orta Düzey (B1- } \\
\text { B2) }\end{array}$ & $\begin{array}{l}\text { Piyano, halk müziği, klasik müzik, pop, caz, bale, dans, Blues, Kelt Müziği, R\&B, } \\
\text { rap, rock, hard, senfonik, pop, progresif, alternatif, punk, heavy metal, } \\
\text { melodika, trompet, klavye, şef, orkestra, resital, gramofon, davul, orkestra, şarkı } \\
\text { söylemek, “aç kapı̈y bezirgân başı" şarkıs, halay, zeybek, horon, ezgi, zurna, } \\
\text { ritim, kemençe, türkü, folklor }\end{array}$ & 39 \\
\hline $\begin{array}{l}\text { Ileri Düzey (C1- } \\
\text { C2) }\end{array}$ & $\begin{array}{l}\text { Flüt, simbal, tef, türkü, çengi, akustik, saray ve tapınak müziği, halk müziği, } \\
\text { enstürümantal, şarkı, bestelenen eser, müzik terapi, şarkı söylemek, müzik aleti } \\
\text { çalmak, müzik dinlemek, ezgi, ritim, melodi, harmoni, kaval, köçek, borazan }\end{array}$ & 22 \\
\hline Toplam & & 71 \\
\hline
\end{tabular}

Tablo 7 incelendiğinde müzik, müzik aletleri ve halk oyunları boyutuna ilişkin temel düzey (A1-A2) ders kitaplarında 10; orta düzey (B1-B2) ders kitabında 39; ileri düzey (C1-C2) ders kitabında 22 ve toplamda 71 unsurla karşılaşılmaktadır. Müzik, müzik aletleri ve halk oyunlarına ilişkin en fazla unsura orta düzey (B1-B2) ders kitaplarında rastlanmaktadır.

Temel düzey (A1-A2) ders kitaplarında kullanılan "piyano" orta düzey (B1-B2) ders kitaplarında da kullanılmıştır. Orta düzey (B1-B2) ders kitaplarında geçen "şarkı söylemek, ezgi, ritim" ifadeleri ileri düzey (C1-C2) ders kitabında da geçmektedir. "Türkü", temel, orta ve ileri olmak üzere üç düzeyde de kullanılmıştır. Müzik aletleri, müzikle ilgili kavram ve ifadeler ile dansla ilgili deyişlere rastlanmaktadır. Müzik türlerinden temel düzey (A1-A2) ders kitaplarında yerel ifadelerden “Türk Sanat Müziği, Türk Halk Müziği, türkü”ye rastlanmış; orta düzey (B1-B2) ders kitaplarında ise evrensel ifadelerden "Blues, Kelt Müziği, R\&B, rap, rock, hard, pop, progresif, alternatif, punk, heavy metal"e rastlanmıştır.

\subsection{Ders kitaplarındaki önemli şahsiyetler unsurlarına yönelik bulgular ve yorum}

Bu bölümde araştırma kapsamında incelenen ders kitaplarında yer alan önemli şahsiyetler boyutuna yönelik kültürel unsurlar ve bu unsurların sıklıkları tablo şeklinde sunulmaktadır.

İncelenen ders kitaplarında önemli şahsiyetler boyutunda yer alan kültürel unsurlar şunlardır:

Tablo 8. Önemli şahsiyetler boyutuna göre ders kitaplarında yer alan kültürel unsurlar

\begin{tabular}{l|l|l}
\hline Dil Düzeyi & Kültürel Unsurlar & $f$ \\
\hline $\begin{array}{l}\text { Temel Düzey (A1- } \\
\text { A2) }\end{array}$ & $\begin{array}{l}\text { Aziz Sancar, Mustafa Kemal Atatürk, Safiye Ayla, Yunus Emre, Taptuk Emre, } \\
\text { Fatih Sultan Mehmet }\end{array}$ & 6 \\
\hline $\begin{array}{l}\text { Orta Düzey (B1- } \\
\text { B2) }\end{array}$ & $\begin{array}{l}\text { Aliye Berger, Fazıl Say, Mithat Fenmen, Kamuran Gökdemir, Muhsin Ertuğrul, } \\
\text { Cahide Sonku, Evliya Çelebi, Hazarfen Ahmet Çelebi, Sultan Murad Han, Reşat } \\
\text { Nuri Güntekin, Necip Fazıl Kisakürek, Peyami Safa, Yahya Kemal Beyatl, } \\
\text { Ahmet Hamdi Akseki, Hamdullah Suphi Tanrı̈̈ver, Attila İlhan, Orhan Pamuk, } \\
\text { Selahaddin Eyyubi, Osman Bey }\end{array}$ & 19 \\
\hline $\begin{array}{l}\text { Ileri Düzey (C1- } \\
\text { C2) }\end{array}$ & $\begin{array}{l}\text { İbn-i Sina, Rufat Ilgaz, Orhan Pamuk, Yaşar Kemal, Leyla Erbil, İlhan Berk } \\
\text { Toplam }\end{array}$ & 6 \\
\hline
\end{tabular}

\footnotetext{
Adres

RumeliDE Dil ve Edebiyat Araşturmalar Dergisi $\quad$ RumeliDE Journal of Language and Literature Studies Osmanağa Mahallesi, Mürver Çiçeği Sokak, No:14/8 $\quad$ Osmanağa Mahallesi, Mürver Çiçeği Sokak, No:14/8 Kadıköy - İSTANBUL / TÜRKIYE 34714 Kadıköy - ISTANBUL / TURKEY 34714 e-posta: editor@rumelide.com e-mail: editor@rumelide.com, tel: +90 505 7958124, +90 2167730616 phone: +90 505 7958124, +90 2167730616
} 
Tablo 8'e bakıldığında önemli şahsiyetler boyutunda temel düzey (A1-A2) ders kitaplarında 6; orta düzey (B1-B2) ders kitaplarında 19; ileri düzey (C1-C2) ders kitabında 6 ve toplamda 31 unsur kullanılmıştır. Önemli şahsiyetlere ilişkin en fazla unsura orta düzey (B1-B2) ders kitaplarında rastlanmıştır.

Ders kitaplarında adı geçen önemli şahsiyetlere bakıldığında temel düzey (A1-A2) ve ileri düzey (C1-C2) ders kitaplarına göre orta düzey (B1-B2) ders kitaplarında daha fazla isme rastlanmaktadır. Orta düzey (B1-B2) ders kitaplarında adı geçen "Orhan Pamuk"un ileri düzey (C1-C2) ders kitabında da adı geçmektedir.

\subsection{Ders kitaplarındaki atasözleri unsurlarına yönelik bulgular ve yorum}

Bu bölümde araştırma kapsamında incelenen ders kitaplarında yer alan atasözleri boyutuna yönelik kültürel unsurlar ve bu unsurların sıklıkları tablo şeklinde sunulmaktadır.

İncelenen ders kitaplarında atasözleri boyutunda yer alan kültürel unsurlar şunlardır:

Tablo 9. Atasözleri boyutuna göre ders kitaplarında yer alan kültürel unsurlar

\begin{tabular}{l|l|l}
\hline Dil Düzeyi & Kültürel Unsurlar & $f$ \\
\hline $\begin{array}{l}\text { Temel Düzey (A1- } \\
\text { A2) }\end{array}$ & & 0 \\
\hline $\begin{array}{l}\text { Orta Düzey (B1- } \\
\text { B2) }\end{array}$ & Vakitsiz öten horozun başı kesilir & 1 \\
\hline $\begin{array}{l}\text { İleri Düzey (C1- } \\
\text { C2) }\end{array}$ & $\begin{array}{l}\text { Ne ekersen onu biçersin, Taşıma suyla değirmen dönmez, Damdan düşenin } \\
\text { halinden damdan düşen anlar }\end{array}$ & 3 \\
\hline Toplam & & 4 \\
\hline
\end{tabular}

Tablo 9’a göre atasözleri boyutuna ilişkin temel düzey (A1-A2) ders kitaplarında o; orta düzey (B1-B2) ders kitaplarında 1; ileri düzey (C1-C2) ders kitabında 3 ve toplamda 4 unsur bulunmaktadır.

Ders kitapları hedef kültürde kullanılan atasözleri bakımından incelendiğinde temel düzey (A1-A2) ders kitaplarında hiçbir atasözüne rastlanmamıştır. Orta düzey (B1-B2) ders kitaplarında sadece "Vakitsiz öten horozun başı kesilir." atasözü kullanılmıştır. "Ne ekersen onu biçersin.", "Taşıma suyla değirmen dönmez.", "Damdan düşenin halinden damdan düşen anlar." atasözleri ise ileri düzey (C1-C2) ders kitabında kullanılmıştır.

\subsection{Ders kitaplarındaki dinî unsurlara yönelik bulgular ve yorum}

Bu bölümde araştırma kapsamında incelenen ders kitaplarında yer alan dinî unsurlar boyutuna yönelik kültürel unsurlar ve bu unsurların sıklıkları tablo şeklinde sunulmaktadır.

İncelenen ders kitaplarında dinî unsurlar boyutunda yer alan kültürel unsurlar şunlardır:

Tablo 1o. Dinî unsurlar boyutuna göre ders kitaplarında yer alan kültürel unsurlar

\begin{tabular}{l|l|l}
\hline Dil Düzeyi & Kültürel Unsurlar & $f$ \\
\hline $\begin{array}{l}\text { Temel Düzey } \\
\text { (A1-A2) }\end{array}$ & $\begin{array}{l}\text { İnanç turizmi, Hristiyan, Tanrı, kilise, mabet, Müslüman, cami, manastır, din, } \\
\text { tasavvuf, farklı dinler, varlı, yokluk, aşk(ilahi aşk kastedilmiştir), Allah, keşiş }\end{array}$ & 16 \\
\hline
\end{tabular}

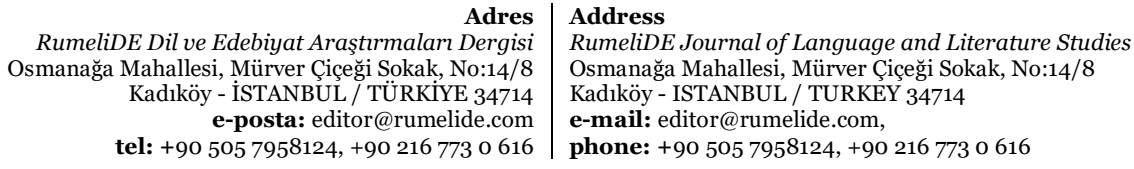




\begin{tabular}{l|l|l}
\hline $\begin{array}{l}\text { Orta Düzey (B1- } \\
\text { B2) }\end{array}$ & $\begin{array}{l}\text { Müslümanlaşma, inanç, Besmele, dua etme, kutsallaştırmak, Kur'an-ı Kerim, } \\
\text { tefsir, hadis, kelam, Tanrı, dindar, tapınak, manastır, cami, kilise, İslami Dönem, } \\
\text { türbe }\end{array}$ & 17 \\
\hline $\begin{array}{l}\text { İleri Düzey (C1- } \\
\text { C2) }\end{array}$ & $\begin{array}{l}\text { Mabet, dua etmek, âlim, Allah'a yalvarmak, Ya Rabbim, kurban vermek, Allah } \\
\text { tarafından taş kesilmek, taş kesilmek, ermiş, dünya tarlası, ahiret, cennet, günah, } \\
\text { sevap, dinsel, Tanrısal güç, İslam dünyası, sarı, âmin, abdest almak, Allah aşkı, } \\
\text { inşallah, sabah ezanı, namaz kılmak, dua yapmak, yatsı namazı, seccade, Allah } \\
\text { affeder, başörtü, namazında niyazında, kıble, beş vakit namaz, Tanrıya } \\
\text { şükretmek, ayet, minare, şehit olmak, cami }\end{array}$ & 37 \\
\hline Toplam & & 70 \\
\hline
\end{tabular}

Tablo 10’a göre dinî unsurlar boyutuna bakıldığında temel düzey (A1-A2) ders kitaplarında 16; orta düzey (B1-B2) ders kitaplarında 17; ileri düzey (C1-C2) ders kitabında 37 ve toplamda 70 unsura rastlanmaktadır. Kitapta geçen dinî unsurların sayısı temel düzey (A1-A2) ders kitaplarında ileri düzey (C1-C2) kitabına doğru artış göstermektedir.

Temel düzey (A1-A2) ve orta düzey (B1-B2) ders kitaplarında "kilise, manastır"; temel düzey (A1-A2) ve ileri düzey (C1-C2) ders kitaplarında "mabet, Allah"; orta düzey (B1-B2) ve ileri düzey (C1-C2) kitaplarında "dua etmek"; üç düzey ders kitabında da "Tanrı, cami” kavramları ortak kullanılmıştır.

\subsection{Ders kitaplarındaki kutlama ve festivaller unsurlarına yönelik bulgular ve yorum}

Bu bölümde araştırma kapsamında incelenen ders kitaplarında yer alan kutlama ve festivaller boyutuna yönelik kültürel unsurlar ve bu unsurların sıklıkları tablo şeklinde sunulmaktadır.

İncelenen ders kitaplarında kutlama ve festivaller boyutunda yer alan kültürel unsurlar şunlardır:

Tablo 11. Kutlama ve festivaller boyutuna göre ders kitaplarında yer alan kültürel unsurlar

\begin{tabular}{l|l|l}
\hline Dil Düzeyi & Kültürel Unsurlar & $f$ \\
\hline $\begin{array}{l}\text { Temel Düzey (A1- } \\
\text { A2) }\end{array}$ & Parti, bayram kutlamak, özel geceler, etkinlik, balo & 5 \\
\hline $\begin{array}{l}\text { Orta Düzey (B1- } \\
\text { B2) }\end{array}$ & $\begin{array}{l}\text { Trafik Haftası, Uluslararası Hemşireler Günü, doğum günü, yılbaşı, Ahududu } \\
\text { Festivali, etkinlik, parti }\end{array}$ & 7 \\
\hline $\begin{array}{l}\text { İleri Düzey (C1- } \\
\text { C2) }\end{array}$ & Cümbüş, tavla partisi, bayram tatili & 3 \\
\hline Toplam & & 15 \\
\hline
\end{tabular}

Tablo 11 incelendiğinde kutlama ve festivaller boyutunda temel düzey (A1-A2) ders kitaplarında 5; orta düzey (B1-B2) ders kitaplarında 7; ileri düzey (C1-C2) ders kitabında 3 ve toplamda 15 unsur bulunmaktadır. Kutlama ve festivallere ilişkin en fazla unsura orta düzey (B1-B2) ders kitaplarında rastlanmıştır.

Temel düzey (A1-A2) ve orta düzey (B1-B2) ders kitaplarında "parti" ifadesi ortak kullanılmıştır.

\subsection{Ders kitaplarındaki Türk âdetleri unsurlarına yönelik bulgular ve yorum}

Bu bölümde araştırma kapsamında incelenen ders kitaplarında yer alan Türk âdetleri boyutuna yönelik kültürel unsurlar ve bu unsurların sıklıkları tablo şeklinde sunulmaktadır.

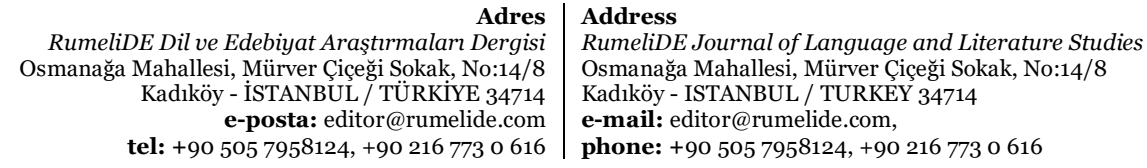


Examination of cultural elements in Turkish textbooks for foreigners: Van Yüzüncü Yll University sample of Turkish teaching set for foreigners / H. Yazıcı; G. Göçen (pp. 365-395)

İncelenen ders kitaplarında Türk âdetleri boyutunda yer alan kültürel unsurlar şunlardır:

Tablo 12. Türk âdetleri boyutuna göre ders kitaplarında yer alan kültürel unsurlar

\begin{tabular}{l|l|l}
\hline Dil Düzeyi & Kültürel Unsurlar & $f$ \\
\hline $\begin{array}{l}\text { Temel Düzey (A1- } \\
\text { A2) }\end{array}$ & Misafirperverlik, misafir olmak & 2 \\
\hline $\begin{array}{l}\text { Orta Düzey (B1- } \\
\text { B2) }\end{array}$ & Düğün, kına yakma, kına gecesi, kına mendilleri, damat tıraşı, güvey giydirme & 6 \\
\hline $\begin{array}{l}\text { İleri Düzey (C1- } \\
\text { C2) }\end{array}$ & Dügün, gelin alayı, düğün alayının önünün kesilmesi, misafir & 4 \\
\hline Toplam & & 12 \\
\hline
\end{tabular}

Tablo 12'ye göre Türk âdetleri boyutunda temel düzey (A1-A2) ders kitaplarında 2; orta düzey (B1-B2) ders kitaplarında 6; ileri düzey (C1-C2) ders kitabında 4 ve toplamda 12 unsur bulunmaktadır. Kitapta geçen Türk âdetleri incelendiğinde en çok orta düzey (B1-B2) ders kitaplarında Türk âdetlerine ilişkin unsurların kullanıldı̆̆ı görülmektedir.

Temel düzey (A1-A2) ve orta düzey (B1-B2) ders kitaplarında "misafir”; orta düzey (B1-B2) ve ileri düzey (C1-C2) ders kitabında ise "düğün” unsurlarının ortak kullanıldığı görülmektedir.

\subsection{Ders kitaplarındaki değerler unsurlarına yönelik bulgular ve yorum}

Bu bölümde araştırma kapsamında incelenen ders kitaplarında yer alan değerler boyutuna yönelik kültürel unsurlar ve bu unsurların sıklıkları tablo şeklinde sunulmaktadır.

İncelenen ders kitaplarında değerler boyutunda yer alan kültürel unsurlar şunlardır:

Tablo 13. Değerler boyutuna göre ders kitaplarında yer alan kültürel unsurlar

\begin{tabular}{|c|c|c|}
\hline Dil Düzeyi & Kültürel Unsurlar & $f$ \\
\hline $\begin{array}{l}\text { Temel Düzey (A1- } \\
\text { A2) }\end{array}$ & $\begin{array}{l}\text { Aile, anne, baba, kardeş, kız kardeş, erkek kardeş, hoşgörü, Van kedisi, Osmanlı } \\
\text { Dönemi, İstanbul'un Fethi, Kurtuluş Mücadelesi, torun }\end{array}$ & 12 \\
\hline $\begin{array}{l}\text { Orta Düzey (B1- } \\
\text { B2) }\end{array}$ & $\begin{array}{l}\text { Anne, baba, amca, oğul, körebe oyunu, birdirbir oyunu, istop oyunu, } \\
\text { bezirgânbaşı oyunu, poşu, yazma, işlik, şal, kuşak, cepken, gömlek, şalvar, } \\
\text { yemeni, çarı, fes, üç etek, mendil, aile, dede, gelin, yenge, Ŏguz Boyları, } \\
\text { Akkoyunlu Devleti, gelenek, töre, Enderun, Osmanlı Devleti, Cumhuriyet, } \\
\text { siyah(matem anlamında), kardeş, Lale Devri, "Birdir bir, ikidir iki, olur tilki... } \\
\text { Üçtür üç, yapması güç... Dörttür dört, kuş gibi öt... Beştir beş, aldım bir eş... } \\
\text { Altıdır altı, yaptım kahvaltı... Yedim yedi, elim sırtına değdi... Sekizim seksek... } \\
\text { Dokuzum durak” }\end{array}$ & 37 \\
\hline $\begin{array}{l}\text { İleri Düzey (C1- } \\
\text { C2) }\end{array}$ & $\begin{array}{l}\text { Selçuklu ve Osmanlı Sarayı, Hititler, Kadeş Savaşı, Kadeş Antlaşması, Frigler, } \\
\text { Lidyalılar, Urartular, el emeği göz nuru, yöresel kıyafetler, sandıklar, nakış, oya, } \\
\text { fes, tülbent, işli ceket, kuşak, şalvar, mest, yazma, iç gömleği, cepken, meşin, } \\
\text { yemeni, kız, söz verme, hükümdar, vezir, oğul, karı-koca, eş-dost, arkadaş, } \\
\text { heybe, komşu, gelenek, töre, sürme, ahbap, nasip, gece tırnak kesilmez, yazın } \\
\text { dere suyu kışı göze suyu içmem, tahtaya vurmak, kapılara at nalı asmak, kırık } \\
\text { ayna, kara kedi, çantayı yere koymak para kaybetmeye sebep olur batıl inancı, } \\
\text { nazar değmesi, aile, sedir, sülale, kardeş, Asurlar, Sümerler, hatun, hanım-bey, } \\
\text { yavrum, ana, semaver, güğüm, kahve(kahvehane anlamında), pastra, al bayrak, } \\
\text { sırma, vatan, aile yadigârı, padişah, evlat, baba, ağabey, oğlan, çırak, "Eline } \\
\text { geçti bir keçi, ne yapacaksın ikiyi, üçü; kessene keçiyi, eline geçti bir at, ye de } \\
\text { yanında yat”, göle yoğurt çalmak, bayram havası, bülbülü altı kafese } \\
\text { koymuşlar ah vatanım demiş, ortalık düğün bayram, darısı başına, ekmeğini }\end{array}$ & 83 \\
\hline
\end{tabular}

\begin{tabular}{r|l} 
Adres & Address \\
RumeliDE Dil ve Edebiyat Araştırmaları Dergisi & RumeliDE Journal of Language and Literature Studies \\
Osmanağa Mahallesi, Mürver Çiçeği Sokak, No:14/8 & Osmanağa Mahallesi, Mürver Çiçeği Sokak, No:14/8 \\
Kadıköy - İSTANBUL / TÜRKIYE 34714 & Kadıköy - ISTANBUL / TURKEY 34714 \\
e-posta: editor@rumelide.com & $\begin{array}{l}\text { e-mail: editor@rumelide.com, } \\
\text { phone: +90 505 7958124, +90 } 2167730616\end{array}$
\end{tabular}




\begin{tabular}{l|l|l}
\hline & $\begin{array}{l}\text { sekerle ye, büyüklerin sözünü dinle, ağaç altında yatma, pirince giderken evdeki } \\
\text { bulgurdan olmak, hayırdır inşallah, "vatan al bayrağın dalgalandığı yer değil } \\
\text { midir?”, "hirsızın hiç mi suçu yok?” }\end{array}$ & \\
\hline Toplam & & 132 \\
\hline
\end{tabular}

Tablo 13'e göre değerler boyutu incelendiğinde temel düzey (A1-A2) ders kitaplarında 12; orta düzey (B1B2) ders kitaplarında 37; ileri düzey (C1-C2) ders kitabında 83 ve toplamda 132 unsurla karşılaşılmaktadır. Orta düzey (B1-B2) ders kitaplarında kullanılan değerlerle ilgili ifadelerin sayısında temel düzey (A1-A2) ders kitaplarına göre artış görülmektedir. İleri düzey (C1-C2) ders kitabında adı geçen değerlere ilişkin unsurların sayısında temel düzey (A1-A2) ve orta düzey (B1-B2) ders kitaplarına göre bir artış olduğu anlaşılmaktadır.

Temel düzey (A1-A2) ve orta düzey (B1-B2) ders kitaplarında "anne"; orta düzey (B1-B2) ve ileri düzey (C1-C2) ders kitaplarında "yazma, kuşak, cepken, şalvar, yemeni, fes, gelenek, töre" ve üç dil düzeyine ait olan ders kitaplarında da "aile, baba, kardeş" ifadeleri ortak kullanılmıştır.

\subsection{Ders kitaplarındaki Türk edebiyatı unsurlarına yönelik bulgular ve yorum}

Bu bölümde araştırma kapsamında incelenen ders kitaplarında yer alan Türk edebiyatı boyutuna yönelik kültürel unsurlar ve bu unsurların sıklıkları tablo şeklinde sunulmaktadır.

İncelenen ders kitaplarında Türk edebiyatı boyutunda yer alan kültürel unsurlar şunlardır:

Tablo 14. Türk edebiyatı boyutuna göre ders kitaplarında yer alan kültürel unsurlar

\begin{tabular}{|c|c|c|}
\hline Dil Düzeyi & Kültürel Unsurlar & $f$ \\
\hline $\begin{array}{l}\text { Temel Düzey (A1- } \\
\text { A2) }\end{array}$ & $\begin{array}{l}\text { Şiir, hikâye, biyografi, gezi, mektup, e-posta, Osmanlı Türkçesi, kitabe, masal, } \\
\text { Keloğlan, şair, Akdamar Adası Efsanesi }\end{array}$ & 12 \\
\hline $\begin{array}{l}\text { Orta Düzey (B1- } \\
\text { B2) }\end{array}$ & $\begin{array}{l}\text { Şiir, öykü, roman, film senaryoları, tiyatro metinleri, kahramanlık destanları, } \\
\text { mektup, gazete, dergi, telgraf, dilekçe, tekerleme, didaktik şiir, epik şiir, satirik } \\
\text { şiir, pastoral şiir, lirik şiir, fabl, hitabet, komedi(yazılan), trajedi(yazılan), } \\
\text { deneme, roman, romantizm, eser, eleştiri, modernizm, realizm, psikolojik } \\
\text { tahliller, hümanizm, mitoloji, Dede Korkut Hikâyeleri, nazım, nesir, deyiş, } \\
\text { atasözleri, sözlü kültür, önsöz, cilt, Seyahatname, sade dil, sürükleyici dil, } \\
\text { Harabelerin Çiçeği, Eski Ahbap, Çallkuşu, Dudaktan Kalbe, Acımak, Yaprak } \\
\text { Dökümü, gezi yazısı, Nihal dergisi, Yeni Mecmua dergisi, Örümcek Ağı, } \\
\text { Kaldırımlar, imgesel anlatım, senaryo, Cevdet Bey ve Ŏgulları, Sessiz Ev, çeviri, } \\
\text { Beyaz Kale, Yeni Hayat, Kar, postmodern, Kara Kitap, Benim Adım Kırmızı, } \\
\text { sürrealist akım, anı, röportaj }\end{array}$ & 67 \\
\hline $\begin{array}{l}\text { İleri Düzey (C1- } \\
\text { C2) }\end{array}$ & $\begin{array}{l}\text { Efsane, sözlü halk kültürü, Gelin Kayaları Efsanesi, Kıztaşı Efsanesi, Ejderha } \\
\text { Efsanesi, Taş Olan Çoban Efsanesi, Şahitlik Kayası Efsanesi, Şahmeran } \\
\text { Efsanesi, Abdurrahman Gazi Efsanesi, "bir varmış bir yokmuş", “evvel zaman } \\
\text { içinde kalbur saman içinde”, mecaz, fikra, masal, “develer tellal, pireler berber } \\
\text { iken, ben anamın anasının beşiğini tıngır mıngır sallar iken, kalbur elek, } \\
\text { kambur felek üstüne söz ederken, ulu mu ulu, yüce mi yüce bir dağ varmış”, az } \\
\text { gitmişler uz gitmişler, onlar ermiş muradına darısı dertlilerin başına, komedi, } \\
\text { mizah, sözlü ve yazılı edebi ürünler, tiyatro, karakter komedisi, töre komedisi, } \\
\text { entrika komedisi, konuşma ve yazı sanatı, hikâye, roman, nükte, öykü, köşe } \\
\text { yazıları, anı, mektup, popüler mizah, siyasi mizah, kara mizah, okuma-yazma, } \\
\text { mitolojik tanrı ve tanrıça, edebi eser, yapıt, şïr, çizgi roman, edebiyat } \\
\text { uyarlamaları, distopik roman, eleştiri, gel zaman git zaman, Keloğlan ve Altın } \\
\text { Bülbül Masalı, Kafdağı }\end{array}$ & 47 \\
\hline Toplam & & 126 \\
\hline
\end{tabular}

Adres

RumeliDE Dil ve Edebiyat Araşturmaları Dergis Osmanağa Mahallesi, Mürver Çiçeği Sokak, No:14/8 Kadıköy - ISTANBUL / TÜRKIYE 34714 e-posta: editor@rumelide.com tel: +90 $5057958124,+902167730616$
Address

RumeliDE Journal of Language and Literature Studies

Osmanağa Mahallesi, Mürver Çiçeği Sokak, No:14/8

Kadıköy - ISTANBUL / TURKEY 34714

e-mail: editor@rumelide.com

phone: +90 5057958124 , +90 2167730616 
Tablo 14'e bakıldığında Türk edebiyatı boyutuna ilişkin temel düzey (A1-A2) ders kitaplarında 12; orta düzey (B1-B2) ders kitaplarında 67; ileri düzey (C1-C2) ders kitabında 47 ve toplamda 126 unsur bulunmaktadır. Türk edebiyatına ilişkin en fazla unsura orta düzey (B1-B2) ders kitaplarında rastlanmaktadır.

Temel düzey (A1-A2) ders kitaplarında verilen "şïr, öykü, gezi, mektup” türlerinin adı orta düzey (B1B2) ders kitaplarında da geçmektedir. Temel düzey (A1-A2) ders kitaplarındaki "masal, efsane"; orta düzey (B1-B2) ders kitaplarındaki "roman, komedi, tiyatro, öykü, mitoloji” edebî türleri ileri düzey (C1C2) ders kitabında da geçmektedir. Ders kitabının bütün düzeylerinde geçen edebî türler ise "şiir, hikâye, mektup"tur.

\subsection{Ders kitaplarındaki görsel sanatlar unsurlarına yönelik bulgular ve yorum}

Bu bölümde araştırma kapsamında incelenen ders kitaplarında yer alan görsel sanatlar boyutuna yönelik kültürel unsurlar ve bu unsurların sıklıkları tablo şeklinde sunulmaktadır.

İncelenen ders kitaplarında görsel sanatlar boyutunda yer alan kültürel unsurlar şunlardır:

Tablo 15. Görsel sanatlar boyutuna göre ders kitaplarinda yer alan kültürel unsurlar

\begin{tabular}{l|l|l}
\hline Dil Düzeyi & Kültürel Unsurlar & $f$ \\
\hline $\begin{array}{l}\text { Temel Düzey (A1- } \\
\text { A2) }\end{array}$ & $\begin{array}{l}\text { Sinema, resim, heykelcilik, mimari, mozaik, sarnıç, İznik Çinileri, çeşme, antik } \\
\text { yapı, mühendislik, Geleneksel Mardin Evleri }\end{array}$ & 11 \\
\hline $\begin{array}{l}\text { Orta Düzey (B1- } \\
\text { B2) }\end{array}$ & $\begin{array}{l}\text { Seramik, heykel, resim, ebru, çini, mimarlık, hüsn-i hatt, cami, kervansaray, } \\
\text { hamam, minare, estetik algısı, mimari, heykel, gravür, grafik, plastik sanatlar, } \\
\text { kabartma, tezhip, minyatür, ritmik sanatlar, tiyatro, sinema, dans, bale, opera, } \\
\text { pandomim, gölge oyunu, müzikal oyun, afiş, karikatür, fotoğraf, Karagöz ile } \\
\text { Hacivat, film, Türk sineması, Ayastefanos'taki Rus Abidesi'nin Yıkılışı filmi, } \\
\text { İstanbul Sokakları filmi, Halıı Kiz filmi, anıt, amfi tiyatro, rölyef, antik kent, } \\
\text { piramit, sergi, tablo, portre, belgesel, açı hava müzesi, peyzaj, gotik mimari, } \\
\text { barok mimari, neoklasik mimari, müze, saray, kale, şato, kule, Geleneksel } \\
\text { Osmanlı Evleri }\end{array}$ & 58 \\
\hline $\begin{array}{l}\text { Ileri Düzey (C1- } \\
\text { C2) }\end{array}$ & $\begin{array}{l}\text { Antsal eserler, saraylar, sosyal yapılar, kaya kabartmaları, orthostatlar (bina } \\
\text { cephelerinde alt sırada yer alan kabartmalı taşlar), seramik, geometrik desen, } \\
\text { hayvan motifi, maden işçiliği, tapınak mimarisi, kuyumculuk sanatı, duvar } \\
\text { resimleri, Kaya Anıtları, dokuma, karikatür, sinema, film, kurgu-fantastik-macera } \\
\text { filmi, bilim-kurgu filmi, resim, fotoğraf }\end{array}$ & 21 \\
\hline Toplam & & 90 \\
\hline
\end{tabular}

Tablo 15'e göre görsel sanatlar boyutuna ilişkin temel düzey (A1-A2) ders kitaplarında 11; orta düzey (B1B2) ders kitaplarında 58; ileri düzey (C1-C2) ders kitabında 21 ve toplamda 90 unsurun kullanıldığ 1 görülmektedir. Orta düzey (B1-B2) ders kitaplarında görsel sanatlara ilişkin unsurlar incelendiğinde temel düzey (A1-A2) ders kitaplarına göre görsel sanat unsurlarının sayısında artış görülmektedir. İleri düzey (C1-C2) ders kitabında kullanılan güzel sanatlar unsurlarının sayısı temel düzey (A1-A2) ders kitaplarına göre artış gösterirken orta düzey (B1-B2) ders kitaplarına göre düşüş göstermektedir.

Temel düzey (A1-A2) ders kitaplarında kullanılan "heykel, mimari, çini” görsel unsurları orta düzey (B1B2) ders kitaplarında da tekrarlanmıştır. "Saray, seramik, karikatür, film, fotoğraf" ifadeleri hem orta düzey (B1-B2) hem de ileri düzeydeki (C1-C2) ders kitaplarında kullanılmıştır. "Sinema, resim" ifadeleri ise bütün dil düzeylerindeki ders kitaplarında kullanılan görsel unsurlardır.

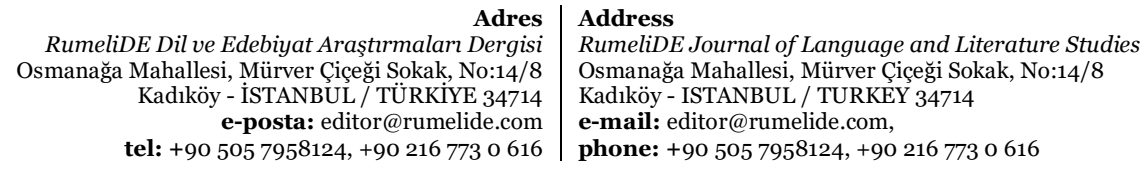




\subsection{Ders kitaplarındaki meslekler unsurlarına yönelik bulgular ve yorum}

Bu bölümde araştırma kapsamında incelenen ders kitaplarında yer alan meslekler boyutuna yönelik kültürel unsurlar ve bu unsurların sıklıkları tablo şeklinde sunulmaktadır.

İncelenen ders kitaplarında meslekler boyutunda yer alan kültürel unsurlar şunlardır:

Tablo 16. Meslekler boyutuna göre ders kitaplarında yer alan kültürel unsurlar

\begin{tabular}{l|l|l}
\hline Dil Düzeyi & Kültürel Unsurlar & $f$ \\
\hline $\begin{array}{l}\text { Temel Düzey (A1- } \\
\text { A2) }\end{array}$ & $\begin{array}{l}\text { Öğretmen, doktor, öğrenci, çaycı, marangoz, eczacı, mühendis, güvenlik } \\
\text { görevlisi, şirket müdürü, avukat, polis, çiftçi, boyacı, hemşire, itfaiyeci, aşçı, } \\
\text { berber, ev hanımı, futbolcu, heykeltıraş, ressam }\end{array}$ & 21 \\
\hline $\begin{array}{l}\text { Orta Düzey (B1- } \\
\text { B2) }\end{array}$ & $\begin{array}{l}\text { Hattat, heykeltıraş, fotoğrafçı, gravür sanatçısı, grafik sanatçısı, virtüöz, } \\
\text { eğitimci, müzikolog, piyanist, ulak, haberci, sosyal medya fenomenliği, } \\
\text { siyasetçi, bürokrat, sporcu, sanatkâr, doktor, müzisyen, solist, piyanist, baterist, } \\
\text { trafik polisi, kemençeci, yazar, romancı, eleştirmen, şair, editör, gazeteci, } \\
\text { ressam, öğretmen, müfettiş, milletvekili, düşünür, bankacı, bakan, öğretim } \\
\text { üyesi, senarist, renk uzmanlı̆̆, denizci, kâşif, hemşire, yönetici, kimyager, bilim } \\
\text { insanı, profesör, rahibe, akademisyen, filozof, başbakan, koruma, oyuncu, } \\
\text { yönetmen, yönetmen yardımcılığı, kameraman, mimar, işçi, asker, çiftçi }\end{array}$ & 59 \\
\hline $\begin{array}{l}\text { İeri Düzey (C1- } \\
\text { C2) }\end{array}$ & $\begin{array}{l}\text { Çoban, elçi, lokman hekim, doktor, hoca, köçek, kasap, akademisyen, blog } \\
\text { yazarları, medya yazarları, reklamcı, çavuş, hokkabaz, hemşire, müzisyen, } \\
\text { filozof, tabip, cerrah, avukat, muhtar, hâkim, yazar, ozan, dağcı, astronot, kadı, } \\
\text { işçi, celep, çiftçi, kaptan, şair, yazar, bilim insanı, profesör, senarist, yönetmen, } \\
\text { film eleştirmeni, hirsız, oyuncu, kaşife, eğitici, hizmetçi }\end{array}$ & 42 \\
\hline Toplam & & 122 \\
\hline
\end{tabular}

Tablo 16'da görüldüğü gibi meslekler boyutuna ilişkin temel düzey (A1-A2) ders kitaplarında 21; orta düzey (B1-B2) ders kitaplarında 59; ileri düzey (C1-C2) ders kitabında 42 ve toplamda 122 unsur bulunmaktadır. Orta düzey (B1-B2) ders kitaplarında, temel düzey (A1-A2) ders kitaplarına göre mesleklerin sayısında artış görülmektedir. İleri düzey (C1-C2) ders kitabında kullanılan meslek sayısı, temel düzey (A1-A2) ders kitaplarına göre artış gösterirken orta düzey (B1-B2) ders kitaplarına göre düşüş göstermektedir.

Temel düzey (A1-A2) ders kitaplarında geçen “öğretmen, doktor, ressam, heykelttraş, polis” meslek grubuna orta düzey (B1-B2) ders kitaplarında da rastlanmaktadır. Temel düzey (A1-A2) ders kitaplarında geçen "avukat” mesleği ileri düzey (C1-C2) ders kitabında da geçmektedir. Orta düzey (B1B2) ders kitaplarında kullanılan "akademisyen, yazar, şair, profesör, senarist, yönetmen, eleştirmen, filozof, oyuncu, hokkabaz, işçi” meslek dalları ileri düzey (C1-C2) ders kitabında da kullanılmıştır. Ayrıca "çoban ve tabip" meslekleri ileri düzey (C1-C2) ders kitabında birden fazla kez tekrar edilmiştir. "Doktor, çiftçi, hemşire" meslekleri ise ders kitabının her düzeyinde adı geçen mesleklerdir.

\subsection{Ders kitaplarındaki turistik ve tarihî yerler unsurlarına yönelik bulgular ve yorum}

Bu bölümde araştırma kapsamında incelenen ders kitaplarında yer alan turistik ve tarihî yerler boyutuna yönelik kültürel unsurlar ve bu unsurların sıklıkları tablo şeklinde sunulmaktadır.

İncelenen ders kitaplarında turistik ve tarihî yerler boyutunda yer alan kültürel unsurlar şunlardır:

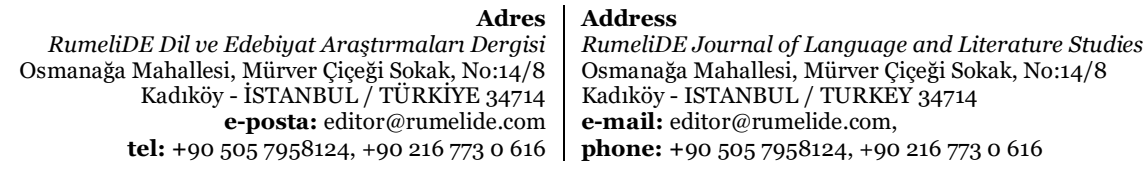


Tablo 17. Turistik ve tarihî yerler boyutuna göre ders kitaplarında yer alan kültürel unsurlar

\begin{tabular}{|c|c|c|}
\hline Dil Düzeyi & Kültürel Unsurlar & $f$ \\
\hline $\begin{array}{l}\text { Temel Düzey (A1- } \\
\text { A2) }\end{array}$ & $\begin{array}{l}\text { İstanbul, Akdeniz, Hakkari, Muğla, Kayseri, Van, Samsun, İzmir, Ankara, } \\
\text { Antalya, Gaziantep, Vatan Caddesi(yol tarifi), Van Gölü, Akdamar Adası, Myra } \\
\text { Antik Kenti, Olimpos Antik Kenti, Aspendos Köprüsü, Gelidonya Feneri, } \\
\text { Mersin, Van Kalesi, Konya, Mardin-Savur, Sultan Ahmet Meydanı, Ayasofya, } \\
\text { Sultan Ahmet Camisi, Yerebatan Sarnıcı, Dikili Taş, Alman Çeşmesi, Mavi } \\
\text { Cami, Fırat Nehri, Güneydoğu Anadolu Bölgesi, Mardin Kalesi, Deyrulzafaran } \\
\text { Manastırı, Ulu Cami, Zinciriye Medresesi, Kırklar Kilisesi, Mardin Müzesi, Dara } \\
\text { Antik Kenti, Eskişehir Sarıköy, Manisa Buna ve Emreköy, Erzurum Dutçu Köyü, } \\
\text { Isparta Keçiborlu, Karaman, Anadolu, Edirne, Amasya }\end{array}$ & 46 \\
\hline $\begin{array}{l}\text { Orta Düzey (B1- } \\
\text { B2) }\end{array}$ & $\begin{array}{l}\text { İstanbul, Ankara, Taksim Galerisi, İstanbul Resim ve Heykel Müzesi, } \\
\text { Diyarbakır, Adana, Anadolu, Ege Bölgesi, Marmara Bölgesi, Batı Anadolu } \\
\text { Bölgesi, Akdeniz Bölgesi, Karadeniz Bölgesi, Galata Kulesi, Üsküdar, } \\
\text { Okmeydanı, Sarayburnu, Sinan Paşa Köşkü, Çanakkale, İzmir, Bursa, Selimiye } \\
\text { Kışlası, Dicle Nehri, Ihlara Vadisi, Aksaray-Güzelyurt, Balıklı Göl, Şanlıurfa, } \\
\text { İzmir-Selçuk, Efes Antik Kenti, Hasankeyf, Nemrut Dağı, Adıyaman, } \\
\text { Cumalıkızı, Kapadokya, Erciyes Dağı, Hasan Dağı, Nevşehir, Trabzon-Maçka- } \\
\text { Altındere Vadisi, Sümela Manastırı, Aspendos, Antalya-Belkıs Köyü, İshak Paşa } \\
\text { Sarayı, Kral Kaya Mezarlıkları, Amasya, Yeşilırmak, Peribacaları }\end{array}$ & 45 \\
\hline $\begin{array}{l}\text { İleri Düzey (C1- } \\
\text { C2) }\end{array}$ & $\begin{array}{l}\text { Boğazkale-Hattuşa, Anadolu, Ankara, Gordion (Yassıhöyük-Polatlı), Afyon, } \\
\text { Eskişehir, Menderes, Gediz Irmakları, Van Gölü, Van (Tuşba), Doğu Anadolu, } \\
\text { Batı Anadolu, Çayönü, Çatalhöyük, Kastamonu, Yozgat, Van-Amik Köyü, } \\
\text { Elazığ-Harput, Ağrı Dağı, Tarsus, Van Kalesi, Bozöyük Köyü, Şanlıurfa- } \\
\text { Göbeklitepe-Örencik Köyü, İstanbul, Haliç, Halıcıoğlu, Akdeniz, Edremit, } \\
\text { Akşehir Gölü }\end{array}$ & 29 \\
\hline Toplam & & 120 \\
\hline
\end{tabular}

Tablo 17 incelendiğinde turistlik ve tarihî yerler boyutuna ilişkin temel düzey (A1-A2) ders kitaplarında 46; orta düzey (B1-B2) ders kitaplarında 45; ileri düzey (C1-C2) ders kitabında 29 ve toplamda 120 unsur kullanılmıştır. İleri düzey (C1-C2) ders kitabında adı geçen yer sayısı temel düzey (A1-A2) ve orta düzey (B1-B2) ders kitaplarına göre düşüş göstermektedir.

Temel düzey (A1-A2) ders kitaplarında geçen “İzmir, Amasya, Antalya, Aspendos, Diyarbakar” orta düzey (B1-B2) ders kitaplarında da geçmektedir. Temel düzey (A1-A2) ders kitaplarında geçen "Eskişehir, Van Gölü, Van Kalesi” yerlerinin adı ileri düzey (C1-C2) ders kitabında da geçmektedir. Orta düzey (B1-B2) ve ileri düzey (C1-C2) ders kitaplarında da yer isimleri "Batı Anadolu, Şanlıurfa" ortak olarak geçmektedir. Temel düzey (A1-A2), orta düzey (B1-B2) ve ileri düzey (C1-C2) ders kitaplarının hepsinde turistik ve tarihî yerler olarak "İstanbul, Ankara, Anadolu, Akdeniz" geçmektedir.

\section{Tartışma}

Yapılan çalışmada Van Yüzüncü Yıl Üniversitesi Yabancılar için Türkçe öğretim setindeki temel (A1-A2), orta (B1-B2) ve ileri (C1-C2) düzey ders kitaplarında yer alan okuma metinlerindeki kültürel unsurlar incelenmiştir.

Araştırma kapsamında incelenen ders kitaplarına bakıldığında açıklayıcı ve bilgi veren metinlerin varlığı dikkat çekmektedir. Ders kitaplarında deneme, biyografi, efsane, gezi yazısı, masal, hikâye ve fikra gibi farklı türlere ilişkin örnekler bulunmaktadır. İleri düzey (C1-C2) ders kitabında Türk edebiyatı olay hikâyeciliği temsilcisi olan Ömer Seyfettin'in "Forsa"; durum hikâyeciliği temsilcilerinden de Sait Faik Abasıyanık'ın "Semaver" isimli hikâyelerine rastlanmaktadır. Ayrıca kitapta dünya edebiyatı durum

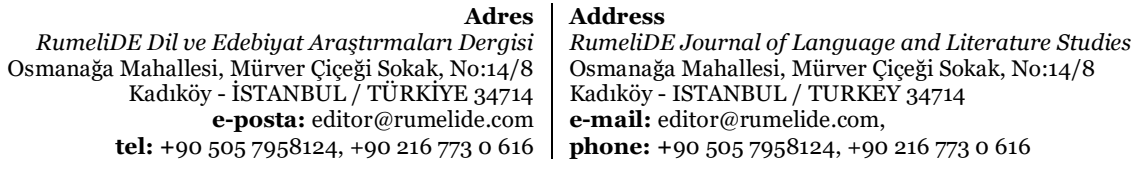


hikâyeciliği temsilcisi Anten Çehov'un "Beceriksiz" isimli hikâyesi de yer almaktadır. Hem Türk hem de dünya edebiyatından bu metin türlerinin örneklerinin olması öğrenicilere karşılaştırma olanağı sağlamaktadır. Orta düzey B2 ders kitabının “Türk Edebiyatı” ünitesinde "Dede Korkut Hikâyeleri” ve "Evliya Çelebi" hakkında bilgi içeren metinler bulunmaktadır. Bu bilgilerin yanında "Dede Korkut Hikâyeleri”"nden bir kesitin ve "Evliya Çelebi”nin seyahat notlarından bir kısmın bulunması öğrenicilere kültür aktarımı bakımından önemlidir. Yine aynı ünitede Türk edebiyatının önemli yazarlarından "Reşat Nuri Güntekin” ve "Orhan Pamuk" hakkında önemli bilgiler içeren metinler bulunmaktadır. Adı geçen yazarların romanlarından alıntılara yer verilmediği görülmektedir. Türk edebiyatının önemli şairlerinden "Attila İlhan" n hayatı hakkında bilgi içeren bir metin de bulunmakta olup şairin şiirlerine ise rastlanmamaktadır.

İncelenen ders kitaplarında hem uluslararası hem de Türk kültürüne ait unsurların birlikte verilmesi kültürlerarası bir öğretim yapılmasına olanak sağlamaktadır. B2 ders kitabının "Çok Gezen Bilir" ünitesinde Türkiye'nin önemli turistik ve tarihî yerleri ile dünyanın önemli ülke ve şehirlerinden "İtalya, New York, Fransa, Almanya, Suriye, Çin ve Irak”tan bahsedilmiştir. Aynı şekilde ders kitaplarında Türk edebiyatının önemli yazarları, onların hayatları ve eserleri ile dünya edebiyatından "Yunan, Fransız, Alman, İngiliz, Amerikan ve Rus Edebiyat”" hakkında bilgi veren okuma metinleri de bulunmaktadır. B2 ders kitabının "İz Brakan Kadınlar" ünitesinde dünyanın farklı ülkelerinde yaşamış, bilimden siyasete önemli işler başarmış kadınların hayatına dair okuma metinleri de bulunmaktadır. Rus işgali karşısında vatan savunmasının sembolü hâline gelen "Nene Hatun", ilk kadın doktorumuz "Safiye Ali", Nato'nun ilk kadın jet pilotu olan "Leman Bozkurt Altınçekiç" ve ilk kadın romancımı "Fatma Aliye" gibi önemli isimlerin hayatlarını anlatan okuma metinleri de ders kitabında yer alabilir.

İncelenen ders kitaplarında Türk kültürüne ilişkin hem güncel hem de geleneksel bilgileri içeren okuma metinleri bulunmaktadır. B1 ders kitabında bulunan "Görsel Sanatlar" isimli metinde geleneksel Türk sanatlarından hat, ebru, çininin yanında geleneksel mimari sanatlarından cami, kervansaray, hamam ve minareden bahsedilmiştir. Ders kitabında hem Türklerin hem de bazı ulusların kültüründe olan geleneksel kukla sanatından "Gölge Oyunu" ile ilgili de okuma metni bulunmaktadır. Türk kültüründe geleneksel oyunlardan olan ve günümüzde de bazı yerlerde hâlâ oynanan "Körebe", "Birdirbir", "İstop”, "Bezirgânbaşı” oyunlarını anlatan "Çocuk Oyunları" isimli bir metin bulunmaktadır. "Türkiye’de Yerel Danslar: Halk Oyunlar" ve "Evlenme Gelenekleri" isimli okuma metinleri, hem geleneksel hem de günümüzde devam eden Türk değer ve geleneklerini ifade etmektedir. İleri düzey (C1-C2) ders kitabında bulunan "Anadolu Medeniyetleri" ile "Yöresel Giyim ve Kuşam" isimli okuma metinleri geleneksel Türk kültürünü yansıtırken "Anadolu Mutfağı” isimli okuma metni hem geçmiş hem de günümüzdeki Türk yemek kültürünü yansıtmaktadır.

Ders kitapları incelendiğinde Türk kültür tarihindeki önemli şahsiyetlerden "Mustafa Kemal Atatürk, Yunus Emre, Fatih Sultan Mehmet, Aliye Berger, Atilla İlhan, Necip Fazıl Kısakürek ve Evliya Çelebi” isimlerine rastlanırken hayatta olan isimlerden "Aziz Sancar, Fazıl Say, Orhan Pamuk"a da rastlanmaktadır. Türk kültürü açısında hem geçmişte yaşamış hem de hayatta olan önemli isimlerin ders kitaplarında yer alması kültür aktarımı açısından önemlidir. Ancak günümüzde yaşayan isimlerin sayısının fazla olmadığı fark edilmektedir.

Ders kitaplarında en fazla geçen kültürel unsurlara bakıldığında; yiyecek, değerler, Türk edebiyatı, meslekler, turistik ve tarihî yerlerle karşılaşılmaktadır. Boyutlarına göre kültürel unsurların en fazla kullanıldığı düzeyler değişmekte olup hepsi için doğru bir orantı yoktur. Türk kültürüne ilişkin birçok 
bilgi barındıran yiyecek, değerler ve Türk edebiyatı boyutlarının fazla kullanılması, hedef dili öğrenenler tarafından kültürümüzün daha iyi anlaşılmasını sağlayabilir. Ders kitaplarında en az kullanılan kültürel unsurlar ise içecek kültürü, atasözleri, kutlama ve festivaller ile Türk âdetleridir.

Düzeyler arasında kültürel unsurların sayısı bakımından çok ciddi bir fark bulunmamaktadır. Öğrenicinin bilgisi ve düzeyi arttıkça kültürel unsur sayısının da artması, hedef kültürün öğrenilmesi bakımından önemli görülmektedir. Kültürel unsurların alt başlıklarındaki artış düzeylere göre dengeli olmasa da toplamda kültürel unsur sayısının temel düzey ders kitaplarından ileri düzey ders kitaplarına doğru arttığı görülmektedir. Türkçenin yabancı dil olarak öğretimini sağlayan diğer ders kitaplarına bakıldığında Yedi İklim Türkçe Seti’nde toplam 259; Yeni Hitit Türkçe Öğretim Seti’nde ise toplam 108 kültürel unsura rastlanmaktadır (Sever, 2019, s. 116). Araştırma kapsamında incelenen ders kitaplarına bakıldığında ise temel düzey (A1-A2) ders kitaplarında 219; orta düzey (B1-B2) ders kitaplarında 414; ileri düzey (C1-C2) ders kitabında 450 ve toplamda 1083 kültürel unsura rastlanmaktadır. Ders kitapları karşılaştırıldığında Van Yüzüncü Yıl Üniversitesi Yabancılar için Türkçe öğretim setindeki kültürel unsur sayısının az olmadığı fark edilmektedir.

Van Yüzüncü Yıl Üniversitesi Yabancılar için Türkçe temel düzey (A1-A2) ders kitaplarında bulunan metinler yerel ve küresel mesajlar içeren bilgilendirici metinlerdir. A1 düzeyi ders kitabında tanışma ifadelerini içeren diyalogların, mesleklerin ve temel düzeye uygun konuların, öğretici kelime ve kelime gruplarının bulunduğu okuma metinlerine rastlanmaktadır. Özellikle "Bir Günüm, Havalimanında, Ailem ve Arkadaşlarım, En Yakın Arkadaşım, Sağlık ve Hastalı, Yeteneklerim, Adres Tarifi, Van Nasıl Bir Şehir, Mektup Arkadaşım” isimli okuma metinlerinin hedef kültürün ana unsurlarını kolaylıkla öğrenmek anlamında temel düzeye uyum gösterdiği düşünülmektedir. A2 düzey ders kitabı incelendiğinde "Aziz Sancar, Yapay Zeka, Hibrit Arabalar, Mustafa Kemal Atatürk ve Sanat, Gelecek Ne Getirecek?, Dünyamız Isiniyor, Yunus Emre, Akdamar Efsanesi, Asla Pes Etme, Fatih Sultan Mehmet" isimli metinler, hem yerel hem de evrensel birçok unsuru barındırmaktadır.

Orta düzey (B1-B2) ders kitaplarında bulunan metinler incelendiğinde kitapların sanatları, sanatçıları, geçmiş ve günümüz iletişimini, kuralları ve sağlı̆̆ı, kültürü, Türk ve dünya edebiyatını, renkleri, dünya üzerinde iz bırakan kadınları, ülkeleri anlatan metinleri içerdiği görülmektedir. B1 düzey kitabına bakıldığında "Görsel Sanatlar, Güzel Sanatlar, Gölge Oyunu, Müzik Türleri, Dünyaca Ünlü Heykeltıraşlar, Aliye Berger, Fazıl Say, Sinema Tarihinde İlk On, Ustanın Dersi, Şampiyon” sanatları, sanatçlları ve sporu; "Geçmişten Bugüne Haberleşme Araçları", "Sosyal Medya mı Asosyal Medya mı?, Çocukve Oyuncaklar, Görsel Medya” geçmiş ve günümüz iletişim durumunu; "Trafik Hayatttr, Sağhkh Bir Hayat için Sporun Önemi, Hangi Sporu Yapsam?, Sağlık için Yararlı Meyve ve Sebzeler" kuralları ve sağlığı; “Çocuk Oyunları, Türkiye’de Yerel Danslar: Halk Oyunlar, Evlenme Gelenekleri” kültürü anlatan metinlerdir. B1 düzeyindeki metinlere bakıldığında sanat, sanatçı, spor, sağlık ve kültür üzerine bilgilendirici, açıklayıcı metinlerle karşılaşılmaktadır. B2 düzeyinde "Yunan, Fransız, Alman, İngiliz, Amerikan ve Rus Edebiyatı, Sohrab Sepehri, Dede Korkut Hikâyeleri, Evliya Çelebi, Reşat Nuri Güntekin, Necip Fazıl Kısakürek, Attila İlhan, Orhan Pamuk" edebiyat ve edebiyatçıları; "Bunları Biliyor musunuz?, Asya Kıtası, Renklerin Büyüsü, Renklerin Festivali: Holi, Gizemli Yapılar" farklı bilgileri; "Lambah Kadın, Marie Curie, İz Brrakan Kadmlarm Unutulmayan Sözleri, Frida Kahlo, Füruğ Ferruhzad, Benazir Butto” iz bırakan kadınları; “İtalya, 5’te 5 New York, Bir Solukta Fransa, Almanya, Suriye, Çin, Irak, Tarihi Zenginlikleriyle Türkiye" ise ülkeleri anlatan metinlerdir. Orta düzey (B1-B2) ders kitaplarında bulunan okuma metinleri farklı konuları, evrensel ve yerel anlamda ele almaktadır.

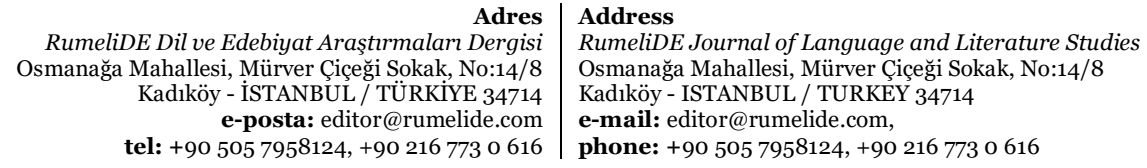

RumeliDE Dil ve Edebiyat Araşttrmaları Dergis (ǘ) tel: +90 $5057958124,+902167730616$ 
İleri düzey (C1-C2) ders kitabı incelendiğinde ilk ünite “Anadolu Mutfağı”nda Türk mutfağındaki önemli yemeklerden, geçmişte Anadolu'da bulunmuş ve varlığını sürdürmüş medeniyetlerden, yöresel kıyafetlerden ve Türk tarihindeki efsanelerden bahsedilmiştir. İkinci ünite olan "Sosyal Medya" ünitesinde sosyal medyanın tanımı, ortaya çıkışı, bağımlılı̆̆ı, gençler üzerindeki etkisi ve kullanım alanları üzerine metinler bulunmaktadır. Üçüncü ünite “İnsana Dair"de dünya üzerinde yaygın batıl inançlar, gülme, korku, müzik ve yaşlanmaya dair metinler vardır. Dördüncü ünite “Sağllk”ta hastalığın nedenleri, çağ hastalıkları, geleneksel tedaviler, sağlıktaki yenilikler ve sağlıkla ilgili önemli haberle alakalı metinlerin bulunduğu ünitedir. Beşinci ünite "Dünyamzz, dünyayla ilgili genel bilgiler, kaynaklar, Mars hakkında bilgi veren metinlerden oluşmaktadır. Son ünite "Edebiyat ve Sinema"da ise edebiyat, sinema, nobel ödülleri, sinema eleştirisi üzerine metinler konu edinilmiştir. Evrensel ve yerel unsurların bir arada bulunduğu bu düzeyde Türk kültüründen çağımızın vazgeçilmezi olan sosyal medyaya, sanattan sağlığa, insandan dünyaya kadar birçok konuya değinilmeye çalışılmıştır.

Araştırma kapsamında incelenen ders kitaplarındaki kültürel unsurlardan kişiler arası iletişim boyutuna bakıldığında temel düzey (A1-A2) ders kitaplarındaki "merhaba, memnun oldum, affedersiniz, iyi günler, hoş geldiniz, günaydın, rica ederim, iyi akşamlar, iyi geceler, afiyet olsun, teşekkür ederim" ifadelerine, Ertuğrul'un (2015, s. 53, 60) çalışmasında incelediği Yeni Hitit Yabancılar için Türkçe temel düzey ve Gazi Yabancılar için Türkçe temel düzey ders kitaplarında da rastlanmaktadır.

Araştırma kapsamında incelenen ders kitaplarındaki kültürel unsurlardan ekonomik hayat boyutuna bakıldığında ileri düzey (C1-C2) ders kitabında geçen "ekmek parası" ifadesi Ertuğrul'un (2015, s. 81) çalışmasında incelediği Yeni Hitit Yabancılar için Türkçe ileri düzey ders kitabında da geçmektedir. Orta düzey (B1-B2) ders kitaplarında ekonomik unsurlar boyutunda rastlanan ve günümüzde gittikçe yaygınlaşmaya başlayan "sanal para, bitcoin" ifadelerine birçok yabancılar için Türkçe ders kitabında rastlanılmamaktadır (Ertuğrul, 2015; Kılıç, 2019; Sever, 2019).

Araştırılan ders kitaplarındaki kültürel unsurlardan millî spor boyutuna bakıldığında orta düzey (B1B2) ders kitaplarında "yüzme, voleybol, basketbol, futbol" spor dallarına rastlanmaktadır. Türkçeye Yolculuk B1 ders kitabında da "yüzme, basketbol, voleybol ve futbol" spor dallarıyla karşılaşılmaktadır (Kılıç, 2016, s. 45). Van Yüzüncü Yıl Üniversitesi Yabancılar için Türkçe ileri düzey (C1-C2) ders kitabında millî sporlardan "cirit oynamak" bulunuyorken Sever'in (2019, s.71) çalışmasında incelediği Yedi İklim Türkçe öğretim setindeki A2 düzeyi ders kitabında da "cirit atmak" ifadesine rastlanmaktadır. Ayrıca Yedi İklim Türkçe öğretim seti C1 düzeyinde (Sever, 2019, s. 71) Türk millî sporlarından "matrak" sporuna rastlanmaktadır. Araştırma kapsamında incelenen ders kitaplarında “matrak" sporu yer almamaktadır.

Araştırma kapsamında incelenen ders kitaplarındaki yiyecek kültürü boyutuna bakıldığında orta düzey (B1-B2) ders kitaplarında "domates, lahana, greyfurt, elma, armut, karpuz, tereyağı, Türk mutfă̆l, beslenme alışkanlıkları, iştah” gibi sebze, meyve, yemekle ilgili ifadelere ve kahvaltı ürünlerinin isimlerine rastlanmaktadır. Van Yüzüncü Yıl Üniversitesi Yabancılar için Türkçe orta düzey (B1-B2) ders kitaplarında geçen "greyfurt, karpuz ve peynir" unsurları Kılıç’ın (2019, s. 43-44) çalışmasında incelediği Türkçeye Yolculuk B1 ders kitabı ile ortaktır. Araştırma kapsamında incelenen orta düzey (B1B2) ders kitaplarındaki yiyecek kültürüyle ilgili ifadelerde Türkçeye Yolculuk B1 ders kitabında ortak unsurlara rastlanırken Türkçeye Yolculuk B2 ders kitabında (Kılıç, 2019) ise ortak unsurlara rastlanmadığı görülmektedir. Özellikle ileri düzey (C1-C2) ders kitabında yiyecek boyutuna ilişkin çorbaların ürünlerine göre "tahıl ve hamur/unla hazırlanan çorbalar, kuru baklagillerle hazırlanan

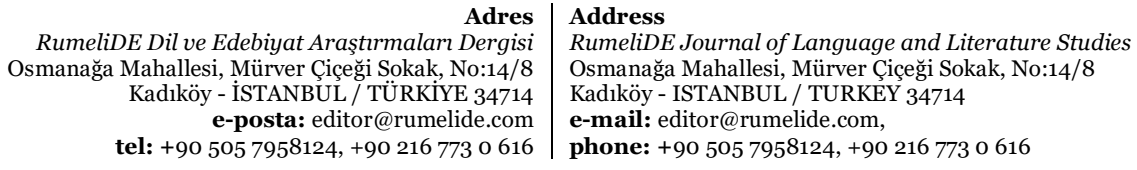


çorbalar, et ve sakatat çorbaları, tavuk ve diğer kümes hayvanı etleriyle hazırlanan çorbalar, yoğurt ve sütle hazırlanan çorbalar, sebze çorbaları" şeklinde tasniflenmesi ve çorba çeşitlerinin "Lebeniye Çorbası, Soğan Çorbası, Yalancı Paça Çorbası, Nohut Çorbası, Bıt Bıt Çorbası, Kırmızı Mercimek Çorbası, Şehriye Çorbası, tutmaç Çorbası, Sebzeli Buğday Çorbası, Ezogelin Çorbası, Sütlü Sebze Çorbası, Domates Çorbası, Tarhana Çorbası, Yayla Çorbası, Aş Otu Çorbası, Hanım Ağa Çorbası, Çeşm-i Nigar Çorbası, Kavata Çorbası, Süleymaniye Çorbası, Meyir Çorbası, Kuş Çorbası” biçiminde detaylı olarak belirtilmesi durumuna diğer ders kitaplarında rastlanmamaktadır. Ayrıca incelenen ders kitaplarında adı geçen "Kanarya Kebap, Mevlana Kebap, Ali Nazik Kebap, Kâğıt Kebabı, Tandır Kebabı, Beyti” kebaplarına da birçok yabancılar için Türkçe ders kitabında rastlanılmamaktadır (Ertuğrul, 2015; Kılıç, 2019; Sever, 2019).

Araştırma kapsamında incelenen ders kitaplarında farklı düzeylerde bulunan içecek kültürü boyutuna bakıldığında "su, çay, kahve, sahlep" gibi içeceklerle karşılaşılmaktadır. Ancak Türk kültüründe önemli yeri olan ve sıklıkla tüketilen "Türk kahvesi” "ne rastlanmamaktadır. "Türk kahvesi” İstanbul Yabancılar için Türkçe B2 düzey ders kitabında (Okur ve Keskin, 2013, s. 1633), Yeni Hitit Yabancılar için Türkçe temel düzey ders kitabında ve Gazi Yabancılar için Türkçe temel ve orta düzey ders kitaplarında yer almaktadır (Ertuğrul, 2015, s. 55-74). Ayrıca incelenen ders kitaplarında "limonata, şalgam” gibi Türk içecek kültüründe önemli yeri olan ifadelerle de karşılaşılmamaktadır. Gazi Yabancılar için Türkçe temel düzey ders kitabında "limonata ve şalgam suyu”yla karşlaşılmaktadır (Ertuğrul, 2015, s. 62).

İncelenen ders kitapları kapsamında müzik, müzik aletleri ve halk oyunlarına ilişkin orta düzey (B1-B2) ders kitapları kültürel unsurlarına bakıldığında yerel halk oyunlarımızdan "zeybek ve horon" ile karşılaşılmaktadır. İstanbul Yabancılar için Türkçe A2 düzey ders kitabında da "zeybek" dansıyla karşılaşılmaktadır (Okur ve Keskin, 2013, s. 1630). Gazi Yabancılar için Türkçe C1 düzey ders kitabında da halk oyunlarından "zeybek ve horon"dan bahsedilmiştir (Ertuğrul, 2015, s. 87). Türk kültüründe ve tarihinde çok önemli bir noktada bulunan yöresel danslara ilişkin temel ifadelerin Türkçenin yabancı dil olarak öğretimi üzerine yazılmış farklı ders kitaplarında da bulunduğu görülmektedir.

Ders kitaplarındaki kültürel unsurların incelenmesindeki başlıklardan biri olan önemli şahsiyetler boyutuna bakıldığında temel düzey (A1-A2) ders kitaplarında hayatta olan, Türk toplumu tarafından yakından tanınan, şarkıları sevilen sanatçılara yer verilmesi ilgi çekicidir. Yeni Hitit Yabancılar için Türkçe temel düzey ders kitabında da "Sezen Aksu, Tarkan" gibi halk tarafından yakından tanınan sanatçllara yer verilmiş̧ir (Ertuğrul, 2015, s. 55). Araştırma kapsamında incelenen temel düzey (A1-A2) ders kitaplarında hayatta olan önemli şahsiyetlerden yalnızca "Aziz Sancar"a; orta düzey (B1-B2) ders kitaplarına bakıldığında ise hayatta olan önemli şahsiyetlerden yalnızca "Fazıl Say ve Orhan Pamuk" isimlerine rastlanmakta olup halk arasında tanınmış yaşayan şarkıcı, oyuncu ya da sporcu isimlerine rastlanmamaktadır. "Fazıl Say"ın ismine Altay Türkçe Öğreniyorum B1 düzey ders kitabında da rastlanmaktadır (Kılıç, 2019, s. 75). İncelenen ders kitaplarında günümüzde yaşayan önemli şahsiyetlere daha çok yer verilebilir.

Araştırma kapsamında incelenen ders kitaplarındaki kültürel unsurlardan atasözleri boyutuna bakıldığında temel düzey (A1-A2) ders kitaplarında atasözlerine rastlanmamaktadır. Orta düzey (B1-B2) ders kitaplarında yalnızca "Vakitsiz öten horozun başı kesilir.” atasözü yer almaktadır. İleri düzey (B1B2) ders kitaplarında ise "Ne ekersen onu biçersin, Taşıma suyla değirmen dönmez, Damdan düşenin halinden damdan düşen anlar." atasözleri bulunmaktadır. "Ne ekersen onu biçersin." atasözüne Gazi Yabancılar için Türkçe ileri düzey ders kitabında da rastlanmaktadır (Ertuğrul, 2015, s. 88). Van

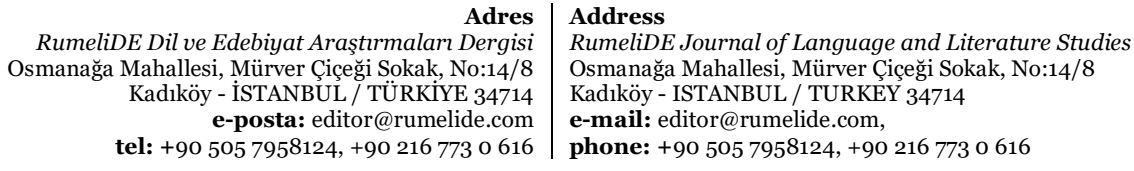


Yüzüncü Yll Üniversitesi Yabancılar için Türkçe öğretim setinde toplamda sadece dört atasözüne rastlanmaktadır. Orta ve ileri düzey ders kitaplarında daha fazla sayıda atasözüne yer verilebilir.

Araştırma kapsamında incelenen ders kitaplarındaki dinî unsurlar kültürel boyutuna bakıldığında temel düzey (A1-A2) ders kitaplarında geçen "cami ve kilise" unsurlarına Yeni Hitit Yabancılar için Türkçe temel seviye ders kitabında da rastlanmaktadır (Ertuğrul, 2015, s. 56). Van Yüzüncü Yıl Üniversitesi Yabancılar için Türkçe ileri düzey (C1-C2) ders kitabı ile Kılıç’ın (2019, s. 61) çalışmasında incelediği Türkçeye Yolculuk B2 ders kitabında "namaz, ezan, Allah, cami, minare" ifadelerinin ortak olduğu görülmektedir.

Araştırma kapsamında incelenen ders kitaplarındaki kutlama ve festivallere ilişkin kültürel unsurlardan yerel olarak yalnızca "Ahududu Festivali”ne rastlanmaktadır. Yeni Hitit Yabancılar için Türkçe orta düzey 2 ders kitabına bakıldığında ise Türkiye'de kutlanan önemli festivallerde olan "Altın Portakal Film Festivali”ne rastlanmaktadır (Ertuğrul, 2015, s. 70). "Altın Portakal Film Festivali” ülkemizde her yl düzenlenen bir tören olduğu için Türkçenin yabancı dil olarak öğretiminde kültür aktarımı konusunda Türk filmleriyle ilgili bilgi verici ve merak uyandırıcı niteliktedir. Bu anlamda incelenen ders kitaplarında bu ve buna benzer kutlama ve festivallere yer verilebilir.

Araştırma kapsamında incelenen orta düzey (B1-B2) ders kitaplarındaki Türk âdetleri kültürel unsur boyutuna bakıldığında "kına yakma, kına gecesi, kına mendilleri" şeklinde evlenme öncesi eğlence kültürüne ilişkin âdetler bulunmaktadır. Altay Türkçe Öğreniyorum Yabancılara Türkçe Öğretimi B1 düzey ders kitabında da evlilik geleneklerine ilişkin "kına gecesi ve kına yakma" ifadelerine rastlanmaktadır (Kılıç, 2019, s. 80). İstanbul Yabancılar için Türkçe A1 düzey ders kitabında da "kına gecesi” ifadesi bulunmaktadır (Okur ve Keskin, 2013, s. 1631). Türk kültüründe yaygın olarak gerçekleştirilen evlilik öncesi geleneklerden "kına gecesi”nin birçok yabancılar için Türkçe ders kitabında kullanıldığı görülmektedir.

Araştırma kapsamında incelenen orta düzey (B1-B2) ders kitaplarının değerler boyutunda "hıdırellez ve nevruz" ders kitaplarında yer alan kültürel unsurlardan bazılarıdır. Yeni Hitit Türkçe öğretim seti B1 orta seviye ders kitabındaki metinlerde bulunan törenlere bakıldığında da "hıdırellez"in tanımının "Hıdırellez: baharda kutlana Türk kültüründe var olan bir bayram" şeklinde verildiği görülmektedir (Sever, 2019, s. 93). İstanbul Yabancılar için Türkçe A1 düzey ders kitabında "hıdırellez" kutlamasına ilişkin ifade bulunmaktadır (Okur ve Keskin, 2013, s. 1631). Yedi iklim Türkçe öğretim seti B1 seviye ders kitabında da törensel davranışlara ilişkin kültürel unsurlardan "nevruz ve hıdırellez" ile karşılaşılmaktadır (Sever, 2019, s. 57). Gazi Yabancılar için Türkçe ileri seviye C1 ders kitabında ise yine "nevruz ve hdrrellez"in adı geçmektedir (Ertuğrul, 2015, s. 89). Türkçenin yabancı dil olarak öğretimindeki farklı ders kitaplarında da "nevruz ve hıdırellez" unsurlarının bulunduğu görülmektedir.

Araştırma kapsamında incelenen ders kitaplarının kültür boyutlarından Türk edebiyatı incelendiğinde temel düzey (A1-A2) ders kitabında "Dev Anası ile Keloğlan"; ileri düzey (C1-C2) ders kitabında da "Keloğlan ve Altın Bülbül Masalı" isimli masallar bulunmaktadır. "Keloğlan Masalı"na Yedi İklim Türkçe öğretim setinde B1 düzeyinde de rastlanmaktadır (Tosun, 2016, s. 34). Türk kültürüne özgü masal karakteri olan Keloğlan'ın adı her iki ders kitabında da geçmektedir. Ancak farklı seviyelerde kullanılmıştır. Van Yüzüncü Yıl Üniversitesi Yabancılar için Türkçe ileri düzey (C1-C2) ders kitabı Türk edebiyatı kültürel boyutu açısından incelendiğinde "Nasrettin Hoca" fikralarına rastlanmaktadır. İstanbul Yabancılar için Türkçe B2 düzey ders kitabına bakıldığında da "Nasrettin Hoca”nın ismiyle karşlaşlmaktadır (Okur ve Keskin, 2013, s. 1634). Türk mizah tarihinin ve fikra türünün önemli

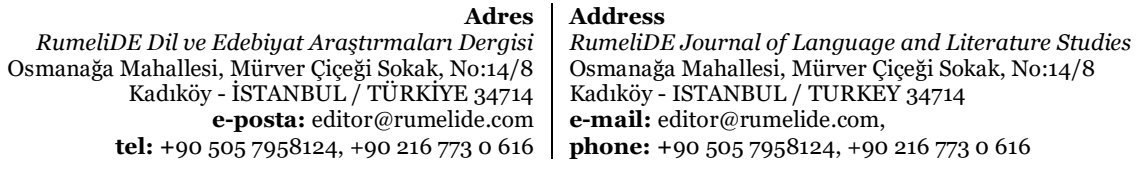


isimlerinden olan Nasrettin Hoca’nın isminin farklı seviyelerde olsa da diğer yabancılar için Türkçe ders kitabında da bulunduğu fark edilmektedir.

Araştırma kapsamında incelenen temel düzey (A1-A2) ders kitaplarındaki görsel sanatlar boyutunda sadece sinema ifadesi bulunmaktadır. Sinema ifadesi de sinema tarihi, gösterimde olan film isimleri ya da oyuncularla ilgili ifadeler şeklinde değil yalnızca arkadaşlar arasında geçen diyaloglarda "sinemaya gitme" şeklinde bulunmaktadır. Filmler kültür aktarımına katkıda bulunmaları ve eğlenceli, ilgi çekici olmaları açısından ders kitaplarında daha fazla yer alabilirler. Yeni Hitit Yabancılar için Türkçe ders kitabına bakıldığında görsel sanatlarla ilgili unsurlara ilişkin "Eyvah Eyvah, Babam ve Oğlum, Vizontele” filmlerine rastlanmaktadır (Ertuğrul, 2015, s. 58). Yedi İklim Türkçe öğretim seti B1 düzey ders kitabında da Türk sinemasına dair "Babam ve Oğlum" filminin adı geçmektedir. Türkçeye Yolculuk B1 düzeyinde Türk sinemasından "Kurtar Beni", "Canım Kardeşim" ve "Uzun Hikaye" filmlerinin adı geçmektedir (Kılıç, 2019, s. 50). Van Yüzüncü Yıl Üniversitesi Yabancılar için Türkçe orta düzey (B1-B2) ders kitaplarında Türk sinemasına ilişkin “Ayastefanos'taki Rus Abidesi”nin Ylkılışı, İstanbul Sokakları ve Hahıı Kız” filmlerinin adı bulunmaktadır. Ayrıca orta düzey (B1-B2) ders kitaplarında gölge oyunu olan "Karagöz ile Hacivat" isimleri bulunmaktadır. Gölge oyunlarından Karagöz ve Hacivat'ın isimleri İstanbul Yabancılar için Türkçe A2 düzey ders kitabında da "Karagöz"; B2 ders kitabında ise "Hacivat ile Karagöz” şeklinde geçmektedir (Okur ve Keskin, 2013, s. 1630-1634).

Araştırma kapsamında incelenen ders kitaplarındaki kültürel unsurlardan meslekler boyutuna bakıldığında temel (A1-A2), orta (B1-B2) ve ileri (C1-C2) düzey olmak üzere tüm düzeylerde geçen "doktor, hemşire, çiftçi” mesleklerine Yeni Hitit Yabancılar için Türkçe temel seviye ders kitabında da rastlanmaktadır (Ertuğrul, 2015, s. 59).

Araştırma kapsamında incelenen ders kitaplarındaki kültürel unsurlardan turistik ve tarihî yerler boyutu incelendiğinde temel düzey (A1-A2) ders kitaplarında "İstanbul, Edirne, Sultan Ahmet Meydanı, Yerebatan Sarnıcı, Ayasofya”; orta düzey (B1-B2) ders kitaplarında ise "Ankara, Üsküdar" adı geçen yerlerden bazılarıdır. Türkçeye Yolculuk B1 düzey ders kitabında "İstanbul, Edirne, Sultan Ahmet Meydan, Yerebatan Sarnıcl, Ayasofya"; B2 düzey ders kitabında da "Ankara ve Üsküdar", Van Yüzüncü Yıl Üniversitesi Yabancılar için Türkçe ders kitaplarıyla örtüşen turistik ve tarihî yer isimlerindendir (Kılıç, 2019, s. 52-65).

\section{Sonuç}

Yapılan çalışmada, Van Yüzüncü Yıl Üniversitesi Yabancılar için Türkçe öğretim setindeki temel (A1A2), orta (B1-B2) ve ileri düzey (C1-C2) ders kitaplarında yer alan okuma metinlerindeki kültürel unsurlar incelenmiştir. İncelenen ders kitaplarında yer alan okuma metinlerinde 1083 kültürel unsurun var olduğu tespit edilmiştir.

Araştırma kapsamında incelenen temel düzey (A1-A2) ders kitaplarında yer alan kültürel unsurlar bir bütün olarak şu şekilde gösterilebilir:

Tablo 18. Temel düzey (A1-A2) ders kitaplarında yer alan kültürel unsurlar

\begin{tabular}{l|l|l}
\hline Kültürel Boyutlar & Temel Düzey (A1-A2) Kültürel Unsurlar & $f$ \\
\hline $\begin{array}{l}\text { Kişiler Arası İletişim } \\
\text { Boyutu }\end{array}$ & $\begin{array}{l}\text { Merhaba, memnun oldum, teşekkür ederim, günaydın, iyi akşamlar, iyi } \\
\text { geceler, görüşürüz, hoşça kal, hoş geldiniz, hoş bulduk, lütfen, afiyet olsun, } \\
\text { ellerine sağllk, buyurun, iyi günler, iyi uçuşlar, tamam, rica ederim, } \\
\text { kendinize iyi bakın, görüş̧mek üzere, affedersiniz, tabi, elbette }\end{array}$ & 23 \\
\hline
\end{tabular}

RumeliDE Dil ve Edebiyat Araştırmaları Dergisi Osmanağa Mahallesi, Mürver Çiçeği Sokak, No:14/8 Kadıköy - ISTANBUL / TÜRKIYE 34714 e-posta: editor@rumelide.com tel: +90 505 7958124, +90 2167730616
Address

RumeliDE Journal of Language and Literature Studies

Osmanağa Mahallesi, Mürver Çiçeği Sokak, No:14/8

Kadıköy - ISTANBUL / TURKEY 34714

e-mail: editor@rumelide.com,

phone: +90 505 7958124, +90 2167730616 


\begin{tabular}{|c|c|c|}
\hline $\begin{array}{l}\text { Ekonomik Hayat } \\
\text { Boyutu }\end{array}$ & $\begin{array}{l}\text { Ne kadar, ücret, finans, ekonomi, ticari, tasarruf, pahalı, masraflı, işsizlik, } \\
\text { sanal para, bitcoin, yoksul, zengin }\end{array}$ & 13 \\
\hline Millî Spor Boyutu & Bisiklet sürmek, yürüyüş & 2 \\
\hline $\begin{array}{l}\text { Yiyecek Kültürü } \\
\text { Boyutu }\end{array}$ & $\begin{array}{l}\text { Kahvaltı, peynir, zeytin, reçel, yumurta, bal, kantin, akşam yemeği, piknik, } \\
\text { boyoz, fistık, inci kefali, Van'ın mutfă̆ı, öğlen yemeği, kebap, döner, } \\
\text { iskender, Türk yemekleri, çiğköfte, kızartma, konserve ürünler, paketlenmiş } \\
\text { gıdalar, yoğurt, enginar, kabak, brokoli, lahana, ıspanak, sebze, yeşil } \\
\text { sebzeler, beslenme, sağlıklı beslenme, abur cubur, obezite, dengesiz } \\
\text { beslenme, atıştırmalıklar }\end{array}$ & 36 \\
\hline İçecek Kültürü Boyutu & Çay, kahve, ayran, su & 4 \\
\hline $\begin{array}{l}\text { Müzik, Müzik Aletleri } \\
\text { ve Halk Oyunları } \\
\text { Boyutu }\end{array}$ & $\begin{array}{l}\text { Piyano, gitar, ney, şarkı söylemek, dans etmek, bale yapmak, saz heyeti, } \\
\text { Türk Sanat Müziği, Türk Halk Müziği, türkü }\end{array}$ & 10 \\
\hline $\begin{array}{l}\text { Önemli Şahsiyetler } \\
\text { Boyutu }\end{array}$ & $\begin{array}{l}\text { Aziz Sancar, Mustafa Kemal Atatürk, Safiye Ayla, Yunus Emre, Taptuk } \\
\text { Emre, Fatih Sultan Mehmet }\end{array}$ & 6 \\
\hline Atasözleri Boyutu & & o \\
\hline Dinî Unsurlar Boyutu & $\begin{array}{l}\text { İnanç turizmi, Hristiyan, Tanrı, kilise, mabet, Müslüman, cami, manastır, } \\
\text { din, tasavvuf, farklı dinler, varlık, yokluk, aşk(ilahi aşk kastedilmiştir), } \\
\text { Allah, keşiş }\end{array}$ & 16 \\
\hline $\begin{array}{l}\text { Kutlama ve Festivaller } \\
\text { Boyutu }\end{array}$ & Parti, bayram kutlamak, özel geceler, etkinlik, balo & 5 \\
\hline Türk Âdetleri Boyutu & Misafirperverlik, misafir olmak & 2 \\
\hline Değerler Boyutu & $\begin{array}{l}\text { Aile, anne, baba, kardeş, kız kardeş, erkek kardeş, hoşgörü, Van kedisi, } \\
\text { Osmanlı Dönemi, İstanbul'un Fethi, Kurtuluş Mücadelesi, torun }\end{array}$ & 12 \\
\hline Türk Edebiyatı Boyutu & $\begin{array}{l}\text { Şiir, hikâye, biyografi, gezi, mektup, e-posta, Osmanlı Türkçesi, kitabe, } \\
\text { masal, Keloğlan, şair, Akdamar Adası Efsanesi }\end{array}$ & 12 \\
\hline $\begin{array}{l}\text { Görsel Sanatlar } \\
\text { Boyutu }\end{array}$ & $\begin{array}{l}\text { Sinema, resim, heykelcilik, mimari, mozaik, sarnıç, İznik Çinileri, çeşme, } \\
\text { antik yapı, mühendislik, Geleneksel Mardin Evleri }\end{array}$ & 11 \\
\hline Meslekler Boyutu & $\begin{array}{l}\text { Öğretmen, doktor, öğrenci, çaycı, marangoz, eczacı, mühendis, güvenlik } \\
\text { görevlisi, şirket müdürü, avukat, polis, çiftçi, boyacı, hemşire, itfaiyeci, aşçı, } \\
\text { berber, ev hanımı, futbolcu, heykeltraş, ressam }\end{array}$ & 21 \\
\hline $\begin{array}{l}\text { Turistik ve Tarihî } \\
\text { Yerler Boyutu }\end{array}$ & $\begin{array}{l}\text { İstanbul, Akdeniz, Hakkari, Muğla, Kayseri, Van, Samsun, İzmir, Ankara, } \\
\text { Antalya, Gaziantep, Vatan Caddesi(yol tarifi), Van Gölü, Akdamar Adası, } \\
\text { Myra Antik Kenti, Olimpos Antik Kenti, Aspendos Köprüsü, Gelidonya } \\
\text { Feneri, Mersin, Van Kalesi, Konya, Mardin-Savur, Sultan Ahmet Meydanı, } \\
\text { Ayasofya, Sultan Ahmet Camisi, Yerebatan Sarnıcı, Dikili Taş, Alman } \\
\text { Çeşmesi, Mavi Cami, Fırat Nehri, Güneydoğu Anadolu Bölgesi, Mardin } \\
\text { Kalesi, Deyrulzafaran Manastırı, Ulu Cami, Zinciriye Medresesi, Kırklar } \\
\text { Kilisesi, Mardin Müzesi, Dara Antik Kenti, Eskişehir Sarıöy, Manisa Buna } \\
\text { ve Emreköy, Erzurum Dutçu Köyü, Isparta Keçiborlu, Karaman, Anadolu, } \\
\text { Edirne, Amasya }\end{array}$ & 46 \\
\hline Toplam & & 219 \\
\hline
\end{tabular}

Tablo 18'e göre temel düzey (A1-A2) ders kitaplarındaki kültürel unsurların sayısı toplamda 219 olarak tespit edilmiştir. Temel düzey (A1-A2) ders kitaplarındaki kültürel boyutlardan en fazla turistik ve tarihî yerlere ilişkin unsurlara rastlanırken atasözleri boyutunda hiçbir kültürel unsura rastlanmamaktadır.

Araştırma kapsamında orta düzey (B1-B2) ders kitabında yer alan kültürel unsurlar bir bütün olarak şu şekilde gösterilebilir:

Adres

RumeliDE Dil ve Edebiyat Araştırmaları Dergisi Osmanağa Mahallesi, Mürver Çiçeği Sokak, No:14/8 Kadıköy - ÍSTANBUL / TÜRKIYE 34714 e-posta: editor@rumelide.com tel: +90 $5057958124,+902167730616$
Address

RumeliDE Journal of Language and Literature Studies Osmanağa Mahallesi, Mürver Çiçeği Sokak, No:14/8

Kadıköy - ISTANBUL / TURKEY 34714

e-mail: editor@rumelide.com,

phone: +90 5057958124, +90 2167730616 
Examination of cultural elements in Turkish textbooks for foreigners: Van Yüzüncü Yll University sample of Turkish teaching set for foreigners / H. Yazıcı; G. Göçen (pp. 365-395)

Tablo 19. Orta düzey (B1-B 2) ders kitaplarında yer alan kültürel unsurlar

\begin{tabular}{|c|c|c|c|}
\hline Kültürel Boyutlar & \multicolumn{2}{|c|}{ Orta Düzey (B1-B2) Kültürel Unsurlar } & $f$ \\
\hline $\begin{array}{l}\text { Kişiler Arası İletişim } \\
\text { Boyutu }\end{array}$ & & & o \\
\hline $\begin{array}{l}\text { Ekonomik Hayat } \\
\text { Boyutu }\end{array}$ & \multicolumn{2}{|c|}{$\begin{array}{l}\text { Ticari maksat, ticari kazanç, para, alışveriş, müşteri, ekonomik sıkıntı, para } \\
\text { biriktirmek }\end{array}$} & 7 \\
\hline Millî Spor Boyutu & \multicolumn{2}{|c|}{$\begin{array}{l}\text { Boks, kick-boks, fitness, voleybol, basketbol, squash, masa tenisi, tenis, } \\
\text { pilates, yürüyüş, koşmak, bisiklet sürmek, futbol, yüzme, su sporu, sırtüstü } \\
\text { yüzme, kurbağalama yüzme, serbest yüzme, kelebek yüzme, karışı yüzme, } \\
\text { karate }\end{array}$} & 21 \\
\hline $\begin{array}{l}\text { Yiyecek Kültürü } \\
\text { Boyutu }\end{array}$ & \multicolumn{2}{|c|}{$\begin{array}{l}\text { Greyfurt, elma, karpuz, sarımsak, domates, beyaz lahana, turunçgil, Türk } \\
\text { mutfağı, armut, balık, tuz, market, beslenme alışkanlıkları, fast food, restoran, } \\
\text { iştah, fırın, bitki, hamur, mısır, mantar, peynir, soğan, zeytin, biber, } \\
\text { dondurma, meyve, tereyağı, pirinç, yöresel lezzetler }\end{array}$} & 30 \\
\hline İçecek Kültürü Boyutu & \multicolumn{2}{|c|}{$\mathrm{Su}$} & 1 \\
\hline $\begin{array}{l}\text { Müzik, Müzik Aletleri } \\
\text { ve Halk Oyunları } \\
\text { Boyutu }\end{array}$ & \multicolumn{2}{|c|}{$\begin{array}{l}\text { Piyano, halk müziği, klasik müzik, pop, caz, bale, dans, Blues, Kelt Müziği, } \\
\text { R\&B, rap, rock, hard, senfonik, pop, progresif, alternatif, punk, heavy metal, } \\
\text { melodika, trompet, klavye, şef, orkestra, resital, gramofon, davul, orkestra, } \\
\text { şarkı söylemek, “aç kapıyı bezirgân başı” şarkısı, halay, zeybek, horon, ezgi, } \\
\text { zurna, ritm, kemençe, türkü, folklor }\end{array}$} & 39 \\
\hline $\begin{array}{l}\text { Önemli Şahsiyetler } \\
\text { Boyutu }\end{array}$ & \multicolumn{2}{|c|}{$\begin{array}{l}\text { Aliye Berger, Fazıl Say, Mithat Fenmen, Kamuran Gökdemir, Muhsin } \\
\text { Ertuğrul, Cahide Sonku, Evliya Çelebi, Hazarfen Ahmet Çelebi, Sultan Murad } \\
\text { Han, Reşat Nuri Güntekin, Necip Fazıl Kısakürek, Peyami Safa, Yahya Kemal } \\
\text { Beyatll, Ahmet Hamdi Akseki, Hamdullah Suphi Tanrı̈̈ver, Attila İlhan, } \\
\text { Orhan Pamuk, Selahaddin Eyyubi, Osman Bey }\end{array}$} & 19 \\
\hline Atasözleri Boyutu & \multicolumn{2}{|c|}{ Vakitsiz öten horozun başı kesilir } & 1 \\
\hline Dinî Unsurlar Boyutu & \multicolumn{2}{|c|}{$\begin{array}{l}\text { Müslümanlaşma, inanç, Besmele, dua etme, kutsallaştırmak, Kur’an-ı Kerim, } \\
\text { tefsir, hadis, kelam, Tanrı, dindar, tapınak, manastır, cami, kilise, İslami } \\
\text { Dönem, türbe }\end{array}$} & 17 \\
\hline $\begin{array}{l}\text { Kutlama ve Festivaller } \\
\text { Boyutu }\end{array}$ & \multicolumn{2}{|c|}{$\begin{array}{l}\text { Trafik Haftası, Uluslararası Hemşireler Günü, doğum günü, yılbaşı, Ahududu } \\
\text { Festivali, etkinlik, parti }\end{array}$} & 7 \\
\hline Türk Âdetleri Boyutu & \multicolumn{2}{|c|}{ Dügün, kına yakma, kına gecesi, kına mendilleri, damat tıraşı, güvey giydirme } & 6 \\
\hline Değerler Boyutu & \multicolumn{2}{|c|}{$\begin{array}{l}\text { Anne, baba, amca, oğul, körebe oyunu, birdirbir oyunu, istop oyunu, } \\
\text { bezirgânbaşı oyunu, poşu, yazma, işlik, şal, kuşak, cepken, gömlek, şalvar, } \\
\text { yemeni, çarı, fes, üç etek, mendil, aile, dede, gelin, yenge, Oğuz Boyları, } \\
\text { Akkoyunlu Devleti, gelenek, töre, Enderun, Osmanlı Devleti, Cumhuriyet, } \\
\text { siyah(matem anlamında), kardeş, Lale Devri, "Birdir bir, ikidir iki, olur tilki... } \\
\text { Üçtür üç, yapması güç... Dörttür dört, kuş gibi öt... Beştir beş, aldım bir eş... } \\
\text { Altıdır altı, yaptım kahvaltı... Yedim yedi, elim sırtına değdi... Sekizim } \\
\text { seksek... Dokuzum durak” }\end{array}$} & 37 \\
\hline Türk Edebiyatı Boyutu & \multicolumn{2}{|c|}{$\begin{array}{l}\text { Şiir, öykü, roman, film senaryoları, tiyatro metinleri, kahramanlık destanları, } \\
\text { mektup, gazete, dergi, telgraf, dilekçe, tekerleme, didaktik şiir, epik şiir, } \\
\text { satirik şiir, pastoral şiir, lirik şïr, fabl, hitabet, komedi(yazılan), } \\
\text { trajedi(yazılan), deneme, roman, romantizm, eser, eleştiri, modernizm, } \\
\text { realizm, psikolojik tahliller, hümanizm, mitoloji, Dede Korkut Hikâyeleri, } \\
\text { nazım, nesir, deyiş, atasözleri, sözlü kültür, önsöz, cilt, Seyahatname, sade dil, } \\
\text { sürükleyici dil, Harabelerin Çiçeği, Eski Ahbap, Çalıkuşu, Dudaktan Kalbe, } \\
\text { Acımak, Yaprak Dökümü, gezi yazısı, Nihal dergisi, Yeni Mecmua dergisi, } \\
\text { Örümcek Ağı, Kaldırımlar, imgesel anlatım, senaryo, Cevdet Bey ve Oğulları, } \\
\text { Sessiz Ev, çeviri, Beyaz Kale, Yeni Hayat, Kar, postmodern, Kara Kitap, Benim } \\
\text { Adım Kırmızı, sürrealist akım, anı, röportaj }\end{array}$} & 67 \\
\hline $\begin{array}{l}\text { Görsel Sanatlar } \\
\text { Boyutu }\end{array}$ & \multicolumn{2}{|c|}{$\begin{array}{l}\text { Seramik, heykel, resim, ebru, çini, mimarlık, hüsn-i hatt, cami, kervansaray, } \\
\text { hamam, minare, estetik algısı, mimari, heykel, gravür, grafik, plastik sanatlar, } \\
\text { kabartma, tezhip, minyatür, ritmik sanatlar, tiyatro, sinema, dans, bale, }\end{array}$} & 58 \\
\hline \multicolumn{2}{|c|}{$\begin{array}{r}\text { Adres } \\
\text { RumeliDE Dil ve Edebiyat Araştrmaları Dergisi } \\
\text { Osmanağa Mahallesi, Mürver Ciçeği Sokak, No:14/8 } \\
\text { Kadıköy - İSTANBUL / TÜRKIYYE } 34714 \\
\text { e-posta: editor@rumelide.com } \\
\text { tel: }+90 \text { 505 7958124, +90 216 } 773 \text { o } 616\end{array}$} & $\begin{array}{l}\text { Address } \\
\text { RumeliDE Journal of Language and Literature Studies } \\
\text { Osmanağa Mahallesi, Mürver Ciçeği Sokak, No:14/8 } \\
\text { Kadıköy - ISTANBUL / TURKEY } 34714 \\
\text { e-mail: editor@rumelide.com, } \\
\text { phone: +90 } 5057958124,+90216773 \text { o } 616\end{array}$ & \\
\hline
\end{tabular}




\begin{tabular}{|c|c|c|}
\hline & $\begin{array}{l}\text { opera, pandomim, gölge oyunu, müzikal oyun, afiş, karikatür, fotoğraf, } \\
\text { Karagöz ile Hacivat, film, Türk sineması, Ayastefanos’taki Rus Abidesi’nin } \\
\text { Ylkılışı filmi, İstanbul Sokakları filmi, Halıcı Kız filmi, anıt, amfi tiyatro, } \\
\text { rölyef, antik kent, piramit, sergi, tablo, portre, belgesel, açlk hava müzesi, } \\
\text { peyzaj, gotik mimari, barok mimari, neoklasik mimari, müze, saray, kale, } \\
\text { şato, kule, Geleneksel Osmanlı Evleri }\end{array}$ & \\
\hline Meslekler Boyutu & $\begin{array}{l}\text { Hattat, heykeltıraş, fotoğrafçı, gravür sanatçısı, grafik sanatçısı, virtüöz, } \\
\text { eğitimci, müzikolog, piyanist, ulak, haberci, sosyal medya fenomenliği, } \\
\text { siyasetçi, bürokrat, sporcu, sanatkâr, doktor, müzisyen, solist, piyanist, } \\
\text { baterist, trafik polisi, kemençeci, yazar, romancı, eleştirmen, şair, editör, } \\
\text { gazeteci, ressam, öğretmen, müfettiş, milletvekili, düşünür, bankacı, bakan, } \\
\text { öğretim üyesi, senarist, renk uzmanlığı, denizci, kâşif, hemşire, yönetici, } \\
\text { kimyager, bilim insanı, profesör, rahibe, akademisyen, filozof, başbakan, } \\
\text { koruma, oyuncu, yönetmen, yönetmen yardımcılığı, kameraman, mimar, işçi, } \\
\text { asker, çiftçi }\end{array}$ & 59 \\
\hline $\begin{array}{l}\text { Turistik ve Tarihî } \\
\text { Yerler Boyutu }\end{array}$ & $\begin{array}{l}\text { İstanbul, Ankara, Taksim Galerisi, İstanbul Resim ve Heykel Müzesi, } \\
\text { Diyarbakır, Adana, Anadolu, Ege Bölgesi, Marmara Bölgesi, Batı Anadolu } \\
\text { Bölgesi, Akdeniz Bölgesi, Karadeniz Bölgesi, Galata Kulesi, Üsküdar, } \\
\text { Okmeydanı, Sarayburnu, Sinan Paşa Köşkü, Çanakkale, İzmir, Bursa, } \\
\text { Selimiye Kışlası, Dicle Nehri, Ihlara Vadisi, Aksaray-Güzelyurt, Balıklı Göl, } \\
\text { Şanlıurfa, İzmir-Selçuk, Efes Antik Kenti, Hasankeyf, Nemrut Dağı, } \\
\text { Adıyaman, Cumalıkızı, Kapadokya, Erciyes Dağı, Hasan Dağı, Nevşehir, } \\
\text { Trabzon-Maçka-Altındere Vadisi, Sümela Manastırı, Aspendos, Antalya- } \\
\text { Belkıs Köyü, İshak Paşa Sarayı, Kral Kaya Mezarlıkları, Amasya, Yeşilırmak, } \\
\text { Peribacaları }\end{array}$ & 45 \\
\hline Toplam & & 414 \\
\hline
\end{tabular}

Tablo 19'a göre orta düzey (B1-B2) ders kitaplarındaki kültürel unsurların sayısı 414 olarak tespit edilmiştir. Orta düzey (B1-B2) ders kitaplarındaki kültürel boyutlardan en fazla Türk edebiyatına ilişkin unsurlara rastlanırken kişiler arası iletişim boyutunda hiçbir kültürel unsura rastlanmamaktadır.

Araştırma kapsamında ileri düzey (C1-C2) ders kitabında yer alan kültürel unsurlar bir bütün olarak şu şekilde gösterilebilir:

Tablo 2o. İleri düzey (C1-C2) ders kitaplarında yer alan kültürel unsurlar

\begin{tabular}{|c|c|c|}
\hline Kültürel Boyutlar & İleri Düzey (C1-C2) Kültürel Unsurlar & $f$ \\
\hline $\begin{array}{l}\text { Kişiler Arası İletişim } \\
\text { Boyutu }\end{array}$ & $\begin{array}{l}\text { Teşekkür etmek, hoş geldin, selamünaleyküm, aleykümselam, teşekkürler, } \\
\text { selam }\end{array}$ & 6 \\
\hline $\begin{array}{l}\text { Ekonomik Hayat } \\
\text { Boyutu }\end{array}$ & $\begin{array}{l}\text { Maden yatakları, ticaret, verimli topraklar, parayı kullanan ilk medeniyet, } \\
\text { tarım ve hayvancılık, Kral Yolu, dokuma tezgâhı, ihtiyaç fazlasını satmak, } \\
\text { geçimini sağlamak, pazar, bakkal, dükkân, terazi, dirhem, ödünç para, borç, } \\
\text { alacaklı, kese, akçe, peşin para, fakir fukara, para kazanmak, açgözlü, cimri, } \\
\text { müşteri, yoksul, maliyet kısmak, finansal kaynak, maliyet, okka, ekmek } \\
\text { parası, ücretli, hasılat, para ödemek, hesap kapatmak, para ihtiyacı, ödeme, } \\
\text { pahalı, aylık }\end{array}$ & 39 \\
\hline Millî Spor Boyutu & Cirit oynamak, egzersiz yapmak, tırmanış & 3 \\
\hline $\begin{array}{l}\text { Yiyecek Kültürü } \\
\text { Boyutu }\end{array}$ & $\begin{array}{l}\text { Beslenme alışkanlı̆̆ı, damak zevki, tarımsal üretim, mutfak kültürü, tahıl, } \\
\text { sebze, zeytinyağl, hamur işi, etle sulu olarak hazırlanan yemekler, pekmez, } \\
\text { yoğurt, bulgur, Türk mutfağı, Gaziantep mutfağı, kebap, et yemekleri, } \\
\text { yoğurtlu yemekler, zeytinyağlı yemekler, tatlı, pilav, sebze yemekleri, köfte, } \\
\text { börek, salata ve piyaz, dolma, Kanarya Kebap, Mevlana Kebap, Ali Nazik } \\
\text { Kebap, Kâğıt Kebabı, Tandır Kebabı, Beyti, tahıl ve hamur/unla hazırlanan } \\
\text { çorbalar, kuru baklagillerle hazırlanan çorbalar, et ve sakatat çorbaları, tavuk } \\
\text { ve diğer kümes hayvanı etleriyle hazırlanan çorbalar, yoğurt ve sütle } \\
\text { hazırlanan çorbalar, sebze çorbaları, Lebeniye Çorbası, Soğan Çorbası, } \\
\text { Yalancı Paça Çorbası, Nohut Çorbası, Bıt Bıt Çorbası, Kırmızı Mercimek }\end{array}$ & 101 \\
\hline
\end{tabular}

Adres

RumeliDE Dil ve Edebiyat Araşturmaları Dergisi Osmanağa Mahallesi, Mürver Çiçeği Sokak, No:14/8 Kadıköy - ISTANBUL / TÜRKIYE 34714 e-posta: editor@rumelide.com tel: +90 505 7958124, +90 2167730616
Address

RumeliDE Journal of Language and Literature Studies Osmanağa Mahallesi, Mürver Çiçeği Sokak, No:14/8

Kadıköy - ISTANBUL / TURKEY 34714

e-mail: editor@rumelide.com,

phone: +90 5057958124 , +90 2167730616 


\begin{tabular}{|c|c|c|c|}
\hline & \multicolumn{2}{|c|}{$\begin{array}{l}\text { Çorbası, Şehriye Çorbası, tutmaç Çorbası, Sebzeli Buğday Çorbası, Ezogelin } \\
\text { Çorbası, Sütlü Sebze Çorbası, Domates Çorbası, Tarhana Çorbası, Yayla } \\
\text { Çorbası, Aş Otu Çorbası, Hanım Ağa Çorbası, Çeşm-i Nigar Çorbası, Kavata } \\
\text { Çorbası, Süleymaniye Çorbası, Meyir Çorbası, Kuş Çorbası, damak tadı, } \\
\text { sağlıklı beslenme, dengeli beslenme, vejeteryan mutfağı, ikram etmek, aç } \\
\text { yatmak, karnını doyurmak, ekmek, şeker, susam, arpa, buğday, açlıktan } \\
\text { kıvranma, kabak, ceviz, çömlek, et, vitamin ve mineral bakımından zengin } \\
\text { yiyecekler, üzüm, fast food, rafineri gıdalar, katkı maddeli yiyecekler, unlu } \\
\text { gıdalar, tuz, katı yağlar, hormonlu gıdalar, bal, propolis, polen, arı sütü, sebze, } \\
\text { meyve, lokma, zahire, balık, restoran, yahni, fesleğen, zencefil, tarçın, badem, } \\
\text { ziyafet çekmek, bir deri bir kemik kalmak }\end{array}$} & \\
\hline İçecek Kültürü Boyutu & \multicolumn{2}{|l|}{$\mathrm{Su}$, alkol, salep, çay } & 4 \\
\hline $\begin{array}{l}\text { Müzik, Müzik Aletleri } \\
\text { ve Halk Oyunları } \\
\text { Boyutu }\end{array}$ & \multicolumn{2}{|c|}{$\begin{array}{l}\text { Flüt, simbal, tef, türkü, çengi, akustik, saray ve tapınak müziği, halk müziği, } \\
\text { enstürümantal, şarkı, bestelenen eser, müzik terapi, şarkı söylemek, müzik } \\
\text { aleti çalmak, müzik dinlemek, ezgi, ritim, melodi, harmoni, kaval, köçek, } \\
\text { borazan }\end{array}$} & 22 \\
\hline $\begin{array}{l}\text { Önemli Şahsiyetler } \\
\text { Boyutu }\end{array}$ & \multicolumn{2}{|c|}{ İbn-i Sina, Rıfat Ilgaz, Orhan Pamuk, Yaşar Kemal, Leyla Erbil, İlhan Berk } & 6 \\
\hline Atasözleri Boyutu & \multicolumn{2}{|c|}{$\begin{array}{l}\text { Ne ekersen onu biçersin, Taşıma suyla değirmen dönmez, Damdan düşenin } \\
\text { halinden damdan düşen anlar }\end{array}$} & 3 \\
\hline Dinî Unsurlar Boyutu & \multicolumn{2}{|c|}{$\begin{array}{l}\text { Mabet, dua etmek, âlim, Allah’a yalvarmak, Ya Rabbim, kurban vermek, Allah } \\
\text { tarafından taş kesilmek, taş kesilmek, ermiş, dünya tarlası, ahiret, cennet, } \\
\text { günah, sevap, dinsel, Tanrısal güç, İslam dünyası, sarık, âmin, abdest almak, } \\
\text { Allah aşkı, inşallah, sabah ezanı, namaz kılmak, dua yapmak, yatsı namazı, } \\
\text { seccade, Allah affeder, başörtü, namazında niyazında, kıble, beş vakit namaz, } \\
\text { Tanrı'ya şükretmek, ayet, minare, şehit olmak, cami }\end{array}$} & 37 \\
\hline $\begin{array}{l}\text { Kutlama ve Festivaller } \\
\text { Boyutu }\end{array}$ & \multicolumn{2}{|c|}{ Cümbüş, tavla partisi, bayram tatili } & 3 \\
\hline Türk Âdetleri Boyutu & \multicolumn{2}{|c|}{ Düğün, gelin alayı, düğün alayının önünün kesilmesi, misafir } & 4 \\
\hline Değerler Boyutu & \multicolumn{2}{|c|}{$\begin{array}{l}\text { Selçuklu ve Osmanlı Sarayı, Hititler, Kadeş Savaşı, Kadeş Antlaşması, Frigler, } \\
\text { Lidyalılar, Urartular, el emeği göz nuru, yöresel kıyafetler, sandıklar, nakış, } \\
\text { oya, fes, tülbent, işli ceket, kuşak, şalvar, mest, yazma, iç gömleği, cepken, } \\
\text { meşin, yemeni, kız, söz verme, hükümdar, vezir, oğul, karı-koca, eş-dost, } \\
\text { arkadaş, heybe, komşu, gelenek, töre, sürme, ahbap, nasip, gece tırnak } \\
\text { kesilmez, yazın dere suyu kışın göze suyu içmem, tahtaya vurmak, kapılara at } \\
\text { nalı asmak, kırık ayna, kara kedi, çantayı yere koymak para kaybetmeye sebep } \\
\text { olur batıl inancı, nazar değmesi, aile, sedir, sülale, kardeş, Asurlar, Sümerler, } \\
\text { hatun, hanım-bey, yavrum, ana, semaver, gügüü, kahve(kahvehane } \\
\text { anlamında), pastra, al bayrak, sırma, vatan, aile yadigârı, padişah, evlat, baba, } \\
\text { ağabey, oğlan, çırak, "Eline geçti bir keçi, ne yapacaksın ikiyi, üçü; kessene } \\
\text { keçiyi, eline geçti bir at, ye de yanında yat”, göle yoğurt çalmak, bayram } \\
\text { havası, bülbülü altın kafese koymuşlar ah vatanım demiş, ortalık düğün } \\
\text { bayram, darısı başına, ekmeğini şekerle ye, büyüklerin sözünü dinle, ağaç } \\
\text { altında yatma, pirince giderken evdeki bulgurdan olmak, hayırdır inşallah, } \\
\text { "vatan al bayrağın dalgalandığı yer değil midir?”, "hırsızın hiç mi suçu yok?” }\end{array}$} & 83 \\
\hline Türk Edebiyatı Boyutu & \multicolumn{2}{|c|}{$\begin{array}{l}\text { Efsane, sözlü halk kültürü, Gelin Kayaları Efsanesi, Kıztaşı Efsanesi, Ejderha } \\
\text { Efsanesi, Taş Olan Çoban Efsanesi, Şahitlik Kayası Efsanesi, Şahmeran } \\
\text { Efsanesi, Abdurrahman Gazi Efsanesi, "bir varmış bir yokmuş", "evvel zaman } \\
\text { içinde kalbur saman içinde”, mecaz, fikra, masal, "develer tellal, pireler } \\
\text { berber iken, ben anamın anasının beşiğini tıngır mıngır sallar iken, kalbur } \\
\text { elek, kambur felek üstüne söz ederken, ulu mu ulu, yüce mi yüce bir dağ } \\
\text { varmış”, az gitmişler uz gitmişler, onlar ermiş muradına darısı dertlilerin } \\
\text { başına, komedi, mizah, sözlü ve yazılı edebi ürünler, tiyatro, karakter } \\
\text { komedisi, töre komedisi, entrika komedisi, konuşma ve yazı sanatı, hikâye, } \\
\text { roman, nükte, öykü, köşe yazlları, anı, mektup, popüler mizah, siyasi mizah, } \\
\text { kara mizah, okuma-yazma, mitolojik tanrı ve tanrıça, edebi eser, yapıt, şiir, } \\
\text { çizgi roman, edebiyat uyarlamaları, distopik roman, eleştiri, gel zaman git } \\
\text { zaman, Keloğlan ve Altın Bülbül Masalı, Kafdağı }\end{array}$} & 47 \\
\hline \multicolumn{2}{|c|}{$\begin{array}{r}\text { Adres } \\
\text { RumeliDE Dil ve Edebiyat Araştrmaları Dergisi } \\
\text { Osmanağa Mahallesi, Mürver Çiceği Sokak, No:14/8 } \\
\text { Kadıköy - ISTANBUL / TÜRKIYE } 34714 \\
\text { e-posta: editor@rumelide.com } \\
\text { tel: +90 505 7958124, +90 216 773 0 616 }\end{array}$} & $\begin{array}{l}\text { Address } \\
\text { RumeliDE Journal of Language and Literature Studies } \\
\text { Osmanağa Mahallesi, Mürver Çiçeği Sokak, No:14/8 } \\
\text { Kadıköy - ISTANBUL / TURKEY } 34714 \\
\text { e-mail: editor@rumelide.com, } \\
\text { phone: +90 505 7958124, +90 } 216773 \text { o } 616\end{array}$ & \\
\hline
\end{tabular}




\begin{tabular}{|c|c|c|}
\hline $\begin{array}{l}\text { Görsel Sanatlar } \\
\text { Boyutu }\end{array}$ & $\begin{array}{l}\text { Anıtsal eserler, saraylar, sosyal yapılar, kaya kabartmaları, orthostatlar (bina } \\
\text { cephelerinde alt sırada yer alan kabartmalı taşlar), seramik, geometrik desen, } \\
\text { hayvan motifi, maden işçiliği, tapınak mimarisi, kuyumculuk sanatı, duvar } \\
\text { resimleri, Kaya Anıtları, dokuma, karikatür, sinema, film, kurgu-fantastik- } \\
\text { macera filmi, bilim-kurgu filmi, resim, fotoğraf }\end{array}$ & 21 \\
\hline Meslekler Boyutu & $\begin{array}{l}\text { Çoban, elçi, lokman hekim, doktor, hoca, köçek, kasap, akademisyen, blog } \\
\text { yazarları, medya yazarları, reklamcı, çavuş, hokkabaz, hemşire, müzisyen, } \\
\text { filozof, tabip, cerrah, avukat, muhtar, hâkim, yazar, ozan, dağcı, astronot, } \\
\text { kadı, işçi, celep, çiftçi, kaptan, şair, yazar, bilim insanı, profesör, senarist, } \\
\text { yönetmen, film eleştirmeni, hırsız, oyuncu, kaşife, eğitici, hizmetçi }\end{array}$ & 42 \\
\hline $\begin{array}{l}\text { Turistik ve Tarihî } \\
\text { Yerler Boyutu }\end{array}$ & $\begin{array}{l}\text { Boğazkale-Hattuşa, Anadolu, Ankara, Gordion (Yassıhöyük-Polatlı), Afyon, } \\
\text { Eskişehir, Menderes, Gediz Irmakları, Van Gölü, Van (Tuşba), Doğu Anadolu, } \\
\text { Batı Anadolu, Çayönü, Çatalhöyük, Kastamonu, Yozgat, Van-Amik Köyü, } \\
\text { Elazı̆g-Harput, Ağrı Dağı, Tarsus, Van Kalesi, Bozöyük Köyü, Şanlıurfa- } \\
\text { Göbeklitepe-Örencik Köyü, İstanbul, Haliç, Halıcığlu, Akdeniz, Edremit, } \\
\text { Akşehir Gölü }\end{array}$ & 29 \\
\hline Toplam & & 450 \\
\hline
\end{tabular}

Tablo 20’ye göre ileri düzey (C1-C2) ders kitabındaki kültürel unsurların sayısı 450 olarak tespit edilmiştir. İleri düzey (C1-C2) ders kitabındaki kültürel boyutlardan en fazla yiyecek kültürüne ilişkin unsurlara rastlanırken en az millî spor, atasözleri ile kutlama ve festivallere ilişkin kültürel unsura rastlanmaktadır.

Araştırma sonucunda Van Yüzüncü Yıl Üniversitesi Yabancılar için Türkçe öğretim setindeki ders kitaplarında yeterli sayıda kültürel unsurun bulunduğu; incelenen ders kitaplarında diğer yabancılar için Türkçe ders kitaplarının çoğunda yer almayan kültürel unsurların da var olduğu tespit edilmiştir. Bununla beraber atasözleri gibi bazı kültürel boyutlarda ders kitaplarında yer alan unsurların sayısının arttırılması gerektiği söylenebilir.

\section{6. Öneriler}

- Yapılan incelemede ders kitaplarında yer alan kültürel unsurlar içinde atasözlerine çok az rastlanmıştır. Ders kitaplarında atasözlerine daha fazla yer verilebilir.

- Yaşayan ve Türk kültürü için önemli olan şarkıcı, sanatçı ya da bilim insanlarının isimlerine okuma metinlerinde daha fazla yer verilebilir.

- Türk edebiyatından şiir örneğine ve romanlardan kesitlere okuma metinleri başlığı altında yer verilebilir.

- Bu çalışma kapsamında seçilen ders kitaplarında yer alan okuma metinlerindeki kültürel unsurlar incelenmiştir. Ayrıca konuşma, yazma, dinleme becerilerine ilişkin metinlerindeki kültürel unsurlara yönelik de çalışmalar yapılabilir.

- Ders kitaplarında yer alan görseller ve görsellerin kültürle ilişkisi gelecek araştırmalarda incelenebilir.

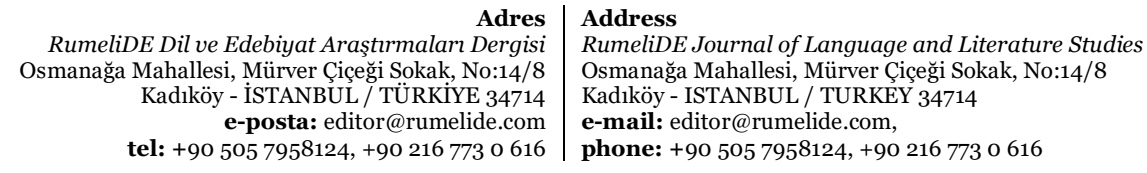




\section{Kaynakça}

Abacıŏ̆lu, T. (2002). Çocuklara oyunlarla yabancı dil öğretimi. Yayımlanmamış yüksek lisans tezi. Gazi Üniversitesi, Eğitim Bilimleri Enstitüsü, Ankara.

Akkoyunlu, B. (2019). Yedi İklim yabancı dil olarak Türkçe setindeki kültürel varlığın incelenmesi. Yayımlanmamış yüksek lisans tezi. Hacettepe Üniversitesi, Türkiyat Araştırmaları Enstitüsü, Ankara.

Bayraktar, S. (2015). Yeni Hitit 1 Yabancılar için Türkçe ders kitabının kültür aktarımı açısından incelenmesi. Hacettepe Üniversitesi Yabancı Dil Olarak Türkçe Araştırmaları Dergisi, 2, 7-23.

Bölükbaş, F. ve Keskin, F. (2010). Yabancı dil olarak Türkçe öğretiminde metinlerin kültür aktarımındaki işlevi. Turkish Studies, 5(4), 221-235.

Çetinkaya, E. (2018). Yabancılara Türkçe öğretimi ders kitaplarında kültürel unsurlar: Yedi İklim Türkçe örneği. Yayımlanmamış yüksek lisans tezi. Gaziosmanpaşa Üniversitesi, Eğitim Bilimleri Enstitüsü, Tokat.

Erdal, K., Dağdeviren, İ., Gökhan, O., Şen, H. H. ve Şenay, E. (2018). Yabancılara Türkçe öğretimi ders kitaplarında kültürel ögeler (A2) düzeyi. TÜRÜKK Uluslararası Dil, Edebiyat ve Halkbilimi Araştırmaları Dergisi, 12, 11-23.

Ertuğrul, M. (2015). Yabancı dil olarak Türkçenin öğretiminde kullanılan kitaplarda kültür aktarımı. Yayımlanmamış yüksek lisans tezi. Gazi Üniversitesi, Eğitim Bilimleri Enstitüsü, Ankara.

İşci, C. (2012). Türkçenin yabancı dil olarak öğretiminde kullanılan "Yeni Hitit" ders kitabının dört temel dil becerisi ve kültür açısından incelenmesi. Yayımlanmamış yüksek lisans tezi. Dokuz Eylül Üniversitesi, Eğitim Bilimleri Enstitüsü, İzmir.

Kaplan, M. (2010). Dil ve kültür. İstanbul: Degâh.

Karakoç Öztürk, B. (2020). Yabancı dil olarak Türkçe öğretiminde somut olmayan kültürel mirasın aktarımı. Çukurova Üniversitesi Türkoloji Araştırmaları Dergisi, 5(2), 288-312.

Keskin, F. (2010). Yetişkinlere yönelik yabancı dil olarak Türkçe derslerinde yazınsal metinlerle kültür aktarımı. Yayımlanmamış yüksek lisans tezi. İstanbul Üniversitesi, Sosyal Bilimler Enstitüsü, İstanbul.

Kılıç, F. (2019). Kültürel ögeler açısından yabancı dil olarak Türkçe öğretiminde kaynak incelemesi: Türkçeye Yolculuk B1-B2 ve Altay Türkçe Öğreniyorum B1-B2 örnekleri. Yayımlanmamış yüksek lisans tezi. Sakarya Üniversitesi, Eğitim Bilimleri Enstitüsü, Sakarya.

Kıral, B. (2020). Nitel bir veri analizi yöntemi olarak doküman analizi. Sosyal Bilimler Enstitüsü Dergisi, $15,170-189$.

Koparan, B. (2019). Yabancı dil olarak Türkçe öğretiminde Türk kültür ögelerinin aktarımına ilişkin öğrenci ve öğretim elemanı görüşleri ile ders kitaplarının inlenmesi. Yayımlanmamış yüksek lisans tezi. Akdeniz Üniversitesi, Eğitim Bilimleri Enstitüsü, Antalya.

Memiş, M. (2016). Yabancı dil öğretiminde eğitim ortamı ve kültür aktarımı. Turkish Studies, 11(9), 605616.

Miles, M., \& Huberman, M. (1994). Qualitative data analysis. Thousand Oaks: CA: Sage.

Mutlu, H. ve Set, G. (2020). Yabancı dil olarak Türkçe öğretiminde kullanılan C1 seviye ders kitaplarındaki kültür unsurlarının incelenmesi (Gazi Yabancılar için Türkçe - İstanbul Yabancılar için Türkçe). Dil Dergisi, 171(1), 91-107.

Okur, A. ve Keskin, F. (2013). Yabancılara Türkçe öğretiminde kültürel ögelerin aktarımı: İstanbul Yabancılar için Türkçe öğretim seti örneği. Jasss International Journal of Social Science, 6(2), 1619-1640.

Ozan Leymun, Ş., Odabaşı, H. F. ve Kabakçı Yurdakul, I. (2017). Eğitim ortamlarında durum çalışmasının önemi. Eğitimde Nitel Araştırmalar Dergisi, 5(3), 369-385.

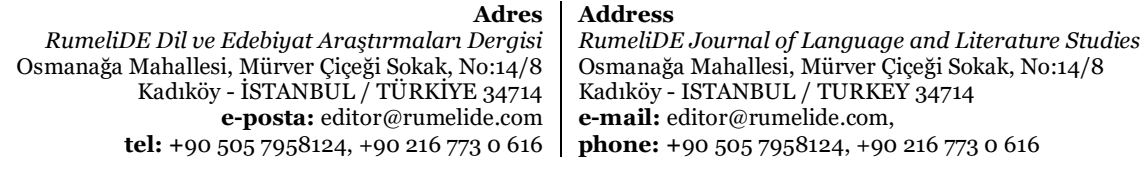


Özgat Tatan, O. (2018). Yabancı dil olarak Türkçe öğretimi ders kitaplarında kültür aktarımı: Yedi İklim Türkçe Öğretim Seti Örneği (A1-A2 Düzeyi). Yayımlanmamış yüksek lisans tezi. Gaziosmanpaşa Üniversitesi, Eğitim Bilimleri Enstitüsü, Tokat.

Saban, A. (2008). Okula ilişkin metaforlar. Kuram ve Uygulamada Eğitim Yöntemi, 55, 459-496.

Saygılı, D. ve Kana, F. (2018). Yabancı dil olarak Türkçe öğreten öğretmenlerin kültürlerarasıllğı duyarlılığı. Ana Dili Eğitimi Dergisi , 6(4), 1041-1063.

Sayid Açıkgöz, E. (2018). Yabancı dil olarak Türkçe öğretimi ders kitaplarında kültür aktarımı: Yeni Hitit Yabancılar için Türkçe ders kitabı: (A1-A2 Düzeyi). Yayımlanmamış yüksek lisans tezi. Gaziosmanpaşa Üniversitesi, Eğitim Bilimleri Enstitüsü, Tokat.

Sever, P. (2019). Yeni Hitit dil öğretim seti ile Yedi İklim dil öğretim setinin Türkçenin yabancı dil olarak öğretiminde kültür aktarımı açısından karşılaştırılması. Yayımlanmamış yüksek lisans tezi. Nevşehir Hacı Bektaş Veli Üniversitesi, Sosyal Bilimler Enstitüsü, Nevşehir.

Subaşı, M. ve Okumuş, K. (2017). Bir araştırma yöntemi olarak durum çalışması. Atatürk Üniversitesi Sosyal Bilimler Enstitüsü Dergisi, 21(2), 419-426.

Tosun, G. (2016). Yedi İklim Türkçe öğretim seti B1, B2 ve C1 seviyesi ders kitaplarındaki metinlerin yabancılara Türkçe öğretiminde kültür aktarımı açısından incelenmesi. Yayımlanmamış yüksek lisans tezi. Başkent Üniversitesi, Eğitim Bilimleri Enstitüsü, Ankara.

Ummak, H. (2018). Yabancı dil olarak Türkçe öğretiminde kullanılan "Kolay Gelsin" ve "İstanbul" ders kitaplarında kültürlerarası öğrenme. Yayımlanmamış yüksek lisans tezi. İstanbul Üniversitesi, Sosyal Bilimler Enstitüsü, İstanbul.

Ülker, N. (2007). "Hitit Ders Kitapları" örneğinde yabancı dil olarak Türkçe öğretiminde kültür aktarımı sürecine çözümleyici ve değerlendirici bir bakış. Yayımlanmamış yüksek lisans tezi. İstanbul Üniversitesi, Sosyal Bilimler Enstitüsü, İstanbul.

Vargelen, H. (2013). Kültürlerarası iletişimsel yeterlilik bağlamında yabancı dil olarak Türkçe öğretimi ders kitaplarının değerlendirilmesi. Yayımlanmamış yüksek lisans tezi. Gazi Üniversitesi, Eğitim Bilimleri Enstitüsü, Ankara.

Yıldırım, A. ve Şimşek, H. (2016). Sosyal bilimlerde nitel araştırma yöntemleri. Ankara: Seçkin.

RumeliDE Dil ve Edebiyat Araşttrmaları Dergisi Osmanağa Mahallesi, Mürver Çiçeği Sokak, No:14/8 Kadıköy - İSTANBUL / TÜRKIYE 34714 e-posta: editor@rumelide.com tel: +90 $5057958124,+902167730616$
Address

RumeliDE Journal of Language and Literature Studies Osmanağa Mahallesi, Mürver Çiçeği Sokak, No:14/8

Kadıköy - ISTANBUL / TURKEY 34714

e-mail: editor@rumelide.com,

phone: +90 5057958124, +90 2167730616 